\title{
The role of Indigenous peoples and local communities in effective and equitable conservation
}

\author{
$\underline{\text { Neil M. Dawson }}^{1,2,3,4}$, Brendan Coolsaet $^{2,3,4}$,Eleanor J. Sterling $^{5}$, Robin Loveridge $^{6,7}$, Nicole D. Gross-Camp $^{8}$, Supin Wongbusarakum \\ ${ }^{9,10,11}, \underline{\text { Kamaljit K. Sangha }}^{12}$, Lea M. Scherl ${ }^{13}$, Hao Phuong Phan $^{14}$, Noelia Zafra-Calvo $^{15}$, Warren G. Lavey $^{16}$, Patrick Byakagaba $^{17}$,

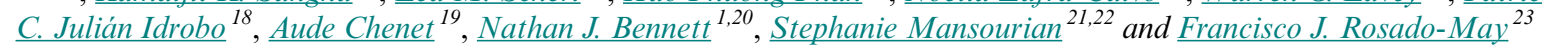

\begin{abstract}
Debate about what proportion of the Earth to protect often overshadows the question of how nature should be conserved and by whom. We present a systematic review and narrative synthesis of 169 publications investigating how different forms of governance influence conservation outcomes, paying particular attention to the role played by Indigenous peoples and local communities. We find a stark contrast between the outcomes produced by externally controlled conservation, and those produced by locally controlled efforts. Crucially, most studies presenting positive outcomes for both well-being and conservation come from cases where Indigenous peoples and local communities play a central role, such as when they have substantial influence over decision making or when local institutions regulating tenure form a recognized part of governance. In contrast, when interventions are controlled by external organizations and involve strategies to change local practices and supersede customary institutions, they tend to result in relatively ineffective conservation at the same time as producing negative social outcomes. Our findings suggest that equitable conservation, which empowers and supports the environmental stewardship of Indigenous peoples and local communities represents the primary pathway to effective long-term conservation of biodiversity, particularly when upheld in wider law and policy. Whether for protected areas in biodiversity hotspots or restoration of highly modified ecosystems, whether involving highly traditional or diverse and dynamic local communities, conservation can become more effective through an increased focus on governance type and quality, and fostering solutions that reinforce the role, capacity, and rights of Indigenous peoples and local communities. We detail how to enact progressive governance transitions through recommendations for conservation policy, with immediate relevance for how to achieve the next decade's conservation targets under the UN Convention on Biological Diversity.
\end{abstract}

Key Words: biodiversity conservation; customary tenure; environmental justice; environmental stewardship; equity; governance; human rights; institutions; IPLC; protected areas; tenure security; traditional ecological knowledge; well-being

\section{INTRODUCTION}

The contribution of Indigenous peoples and local communities (IPLCs) to effective biodiversity conservation has gained recognition, particularly since the 2003 World Parks Congress in Durban, South Africa (Brosius 2004, Diaz et al. 2019). Involving IPLCs is perceived as important not only because it makes conservation more equitable, but also because it has the potential to produce better biodiversity outcomes or more effective conservation (Posey 1999, Borrini-Feyerabend et al. 2004, Garnett et al. 2018, Reyes-García et al. 2019). Progress toward recognition of the role of IPLCs in conservation has included the promotion of rights-based approaches (Roe et al. 2010), the combination of social and ecological goals as in the Aichi Targets of the Convention on Biological Diversity (CBD; Gannon et al. 2019), the development of standards and assessment tools for conservation governance and social impacts (Borrini-Feyerabend et al. 2013, Zafra-Calvo et al. 2017, CBD 2018, Hockings et al. 2019), and the inclusion of local governance efforts or "other effective conservation measures" within the global network of conserved areas (Jonas et al. 2014, Dudley et al. 2018).

Yet, while many funders and practitioners have adopted the rhetoric of equitable and inclusive conservation, these principles have had less impact on site-level governance, creating a gap between policy and practice (Witter and Satterfield 2019). For multilateral policy debates such as the post-2020 Global Biodiversity Framework of the CBD, the discussion of what proportion of the planet to conserve has received greater attention than how it should be conserved (Bhola et al. 2021). Although a wide spectrum of governance types exists, externally controlled forms are commonly initiated based on the narrative that environmental degradation is caused by the material dependence

\footnotetext{
${ }^{1}$ Commission on Environmental, Economic and Social Policy, International Union for the Conservation of Nature, ${ }^{2}$ European School of Political and Social Sciences (ESPOL), Lille Catholic University, Lille, France, ${ }^{3}$ Centre for the Synthesis and Analysis of Biodiversity (CESAB), French Foundation for Research on Biodiversity (FRB), Montpellier, France, ${ }^{4}$ Global Environmental Justice Group, School of International Development, University of East Anglia, Norwich, UK, ${ }^{5}$ Center for Biodiversity and Conservation, American Museum of Natural History, USA, ${ }^{6}$ Department of Environment and Geography University of York, UK, ${ }^{7}$ The Biodiversity Consultancy, Cambridge, UK, ${ }^{8}$ Royal Botanic Garden Edinburgh, Edinburgh, UK, ${ }^{9}$ One People One Reef, ${ }^{10}$ University of Hawai i Sea Grant College Program, ${ }^{11}$ Department of Natural Resources and Environmental Management, University of Hawai'i at Manoa, ${ }^{12}$ Darwin Centre for Bushfire Research (DCBR), Research Institute for the Environment and Livelihoods (RIEL), Charles Darwin University, Darwin, Australia, ${ }^{13}$ The Cairns Institute, James Cook University, Australia, ${ }^{14}$ Institute of Education, University College London, UK, ${ }^{15}$ Basque Centre for Climate Change, Scientific Campus of the University of the Basque Country, Bilbao, Spain, ${ }^{16}$ School of Earth, Society \& Environment and College of Law, University of Illinois, ${ }^{17}$ School of Forestry, Environmental and Geographical Sciences, Makerere University, Kampala, Uganda, ${ }^{18}$ Aurora Research Institute, Aurora College, Canada, ${ }^{19}$ Climate Change and Environmental Sustainability, The Pacific Community (SPC), Noumea, ${ }^{20}$ The Peopled Seas Initiative, Vancouver, British Columbia, Canada, ${ }^{21}$ Mansourian.org, Crassier, Switzerland, ${ }^{22}$ University of Geneva, Geography and Environment Department, Geneva, Switzerland, ${ }^{23}$ Universidad Intercultural Maya de Quintana Roo, Mexico
} 
of IPLCs who lack capacity to manage biodiversity sustainably (Delabre et al. 2020, Skutsch and Turnhout 2020). This logic underpins initiatives that aim to protect biodiversity from IPLCs through management regimes that exclude local practices and override customary institutions (West et al. 2006, Büscher and Fletcher 2019). However, attempts to separate biodiversity and local livelihoods have yielded limited success: biodiversity often declines at the same time as the well-being of those who inhabit areas targeted for interventions (Christoplos et al. 2009, Ferraro and Hanauer 2011, Hirsch et al. 2011, Howe et al. 2014, Agrawal and Redford 2009, Mbaria and Ogada 2016).

Locally empowered environmental stewardship represents a counter-narrative to conservation efforts that seek to separate IPLCs' livelihoods from biodiversity (Chapin et al. 2010, Curtin 2014, Lliso et al. 2020). The well-being of IPLCs is typically bound to nature, and species and ecosystems have, in some cases, been sustainably managed over long timescales by those communities (Posey 1999, Diaz et al. 2019, von der Porten et al. 2019). Several recent studies have shown a positive association between the degree of engagement of IPLCs in conservation efforts and achievement of ecological and/or social outcomes, across regions, ecosystems, and intervention types (Persha et al. 2011, Bridgewater et al. 2015, Oldekop et al. 2016, Blackman et al. 2017, Schleicher et al. 2017, Garnett et al. 2018, Mcleod et al. 2019). However, the pathways through which the role of IPLCs and characteristics of governance interact to produce different social and ecological outcomes have not been well explored, precluding a common understanding of these dynamics (Ferraro and Hanauer 2015, Bhola et al. 2021).

To address this knowledge gap, we conducted a review of the social and ecological outcomes arising from different forms of conservation governance and identified common pathways through which they occur. Only studies that empirically evidenced both social and ecological outcomes, and links between them, were included in the analysis.

\section{Well-being, governance, and conservation effectiveness}

Contemporary understanding of biodiversity conservation increasingly treats the social and ecological dimensions as inseparable (Guerrero et al. 2018, Liu et al. 2018). This review builds on the idea that beyond its environmental objectives, conservation serves to support the rights and well-being of IPLCs. We wish to explore not only the social outcomes of conservation, but also the social inputs, including values, practices, and actions (specifically of IPLCs) that may shape the social and ecological outcomes of conservation. In so doing, we adopt a definition of well-being that is holistic and adaptable to different contexts, encompassing not only material livelihood resources such as income and assets but also health and security as well as subjective social, cultural, psychological, political, and institutional factors (Gough and McGregor 2007). All of the latter elements are increasingly considered as potential social impacts of conservation (Breslow et al. 2016).

Such holistic approaches regard a person's well-being as an ongoing process shaped by interactions with others and the surrounding physical environment rather than just a state to be attained by an individual (Coulthard et al. 2011). In the context of biodiversity conservation, governance refers to who makes what decisions, as well as to the set of regulatory processes, mechanisms, and organizations through which different actors influence and become responsible for specific outcomes (Lemos and Agrawal 2006). Governance and the well-being of IPLCs therefore partially overlap because key elements of local decision making such as knowledge, customary institutions, and autonomy are also aspects of a person's well-being (Lebel et al. 2006, Thornton et al. 2019). Accordingly, these social resources represent potential contributions to governance as well as constituting some of the positive or negative social impacts that may arise from conservation efforts. However, as clarified and described through examples below, this conceptual overlap does not predetermine our findings, i.e., greater participation automatically equals enhanced well-being, because it represents only a fraction of the more complex dynamics through which governance, well-being, and conservation effectiveness are linked.

In this review, we build on Nagendra and Ostrom's (2012) distinction between externally controlled and locally controlled governance arrangements. Although the former refers to management regimes that are controlled by external actors, e.g., the state, NGOs, private firms, etc., and tend to exclude local practices and institutions, the latter is consistent with a shift to decentralized or nested forms of governance (Salomon et al. 2018) that include local informal and unwritten customary systems covering use, control, and authority over natural resources by IPLCs (Schlager and Ostrom 1992). However, while reviewing studies and characterizing cases we also recognized that many conservation initiatives may have hybrid collaborative arrangements that can change over time in terms of the relative contribution of external versus local agents. As with well-being and governance, we adopted a broad definition of conservation effectiveness that can be represented by various ecological indicators, such as land or resource uses, elements of biodiversity, or ecosystem services, and can have multiple interpretations depending on different actors' perceptions or priorities (Cook et al. 2019).

Well-being, governance, and conservation effectiveness are linked through pathways, which this review seeks to better understand. We use the term pathways to describe the possible processes through which different forms of governance are associated with certain combinations of outcomes, both social and ecological. For the pathways identified through this review, we describe the nature of the relationship, e.g., positive/negative or direct/indirect, and, additionally, aim to capture and synthesize the complex dynamics reported to influence that relationship in the reviewed cases. The analytical framework we apply is commensurate with a complex social-ecological systems approach (Folke et al. 2005). We consider the factors influencing these relationships to include political, economic, social, institutional, and environmental drivers that are not confined to the local scale or the "conservation sector," but instead form interrelated dynamics that span spatial, temporal, jurisdictional, and sectoral scales (Cash et al. 2006, Armitage et al. 2012, Borrini-Feyerabend and Hill 2015, Woodhouse and McCabe 2018).

\section{METHODS}

\section{Literature search}

We designed a search for peer-reviewed literature, targeting publications that addressed an aspect of human well-being and 
that also explored conservation effectiveness. We sought to include different types of evidence, whether quantitative, qualitative, or mixed methods, from multiple disciplines that may use diverse terminology. Accordingly, we began with a process of identifying a range of terms for inclusion in the literature search (described in Appendix 1). Our final search string, using the Web of Science core collection from 1945 to September 2019, included more than one hundred search terms, comprising a wide variety of possible subcomponents and synonyms for each component (Appendix 1). The search returned 3100 peer-reviewed items.

\section{Selection criteria}

To sift through this large and diverse set of 3100 studies, we used three inclusion criteria, selecting publications for full data extraction if they appeared to (1) present empirical evidence about the well-being of IPLCs; (2) present empirical evidence about conservation effectiveness; and (3) present empirical evidence about links between them. For example, if a study presented data on deforestation rates as an indicator of conservation effectiveness and described aspects of the lives of people living in the area such as education or poverty levels, yet provided no analysis, quantitatively or qualitatively, to evidence a relationship between them, then that study was excluded. We utilized Colandr software, which employs machine learning to identify, from the titles and abstracts, the publications most likely to meet the selection criteria based on the researchers' screening decisions (Cheng et al. 2018). After screening abstracts, 307 peer-reviewed publications were selected for inclusion and full reading. Through full review the number included was cut to 169 (see Table A2.1 for full list of included studies and Appendix 3 for additional detail of the screening process).

\section{Review protocol}

Because of the exploratory nature of our review, breadth of terminology, diversity of disciplinary approaches within the sample, and the potential complex links between them, we opted for a narrative synthesis method (Popay et al. 2006), through which extensive qualitative information was extracted. The review protocol (Table A3.1) was designed to capture details of the conservation intervention or practices, governance context, research approach, findings related to human well-being, conservation effectiveness, links between well-being and effectiveness, and key factors affecting that relationship. Geographic location, ecosystem type, and research approach were recorded to facilitate categorization and comparative analyses.

\section{Coding procedure $I$ analysis}

In order to synthesize this body of evidence, the detailed descriptive data extracted from each of the 169 publications was coded thematically and iteratively (Snilstveit et al. 2012). First, thematic analysis was conducted to provide three categories to facilitate comparative analysis (Ayala-Orozco et al. 2018): the social research approach applied in each study; the governance type described; and the combination of social and ecological outcomes observed (see Table A3.1 for specific variables recorded).

The social research approach applied in each study was classified based on extracted information that described the definition of well-being adopted, methods used, and any assumptions recorded (Table A3.1). Each of the 169 studies was allocated to one of three categories: those with a highly material focus on income or physical assets; a holistic approach exploring subjective values, relational aspects of well-being, and other social, cultural, and political elements beyond the material; and third, those that were intermediate, going beyond a purely material focus to include some aspect of participation or social capital, though giving little attention to socio-cultural and relational dimensions.

The categorization of governance was derived from information entered under governance arrangements, power relations, intervention details, objectives, and targets (Table A3.1). The key criteria were whether local formal or customary institutions pertaining to resource tenure, cultural practice, or decision making formed part of governance arrangements versus situations of passive consultation or where decisions were imposed and local institutions replaced by externally controlled structures. The description of conservation governance was coded into three categories: externally controlled governance, whether by state, private enterprises, non-governmental organizations, or a combination; locally controlled governance where local communities exerted a primary influence on and their own institutions played a core role in governance, whether completely autonomously, a form of collaborative governance with external actors, or some shared or divided responsibilities; and a third category of externally controlled governance but for commercial purposes including forestry, extractives, or agriculture, rather than conservation-oriented.

The findings presented in each publication about the well-being of IPLCs and conservation effectiveness were separately categorized based on whether the outcomes were reported as exclusively positive or negative, neutral or negligible, or complex. These sets of social and ecological outcomes or trends were then paired to denote whether each study presented their case of focus as a concurrent positive outcome for IPLCs and conservation, a jointly negative set of outcomes, a trade-off where conservation was effective at the expense of human well-being, or vice-versa where well-being improved at the expense of conservation effectiveness, or where the outcomes were too complex to be assigned. Cases were categorized as exhibiting complex outcomes if some people in a community gained while others were impacted negatively, if people initially gained but lost out in some way over time, or if some aspect of biodiversity increased while another declined. The total numbers of these sets of outcomes were then tallied and their proportions calculated for each governance type, social research approach, and region. Importantly, none of the reviewed publications reduced the social outcomes to only participation in conservation, or simply assumed that a greater role in governance for IPLCs automatically enhances their wellbeing, which could lead to false conclusions. The examples detailed throughout the results clearly present a more diverse and profound set of social impacts.

For the second part of the analysis, the qualitative data extracted from each study were analyzed thematically to describe the dynamics driving those relationships between governance, wellbeing, and conservation effectiveness. The analysis enabled characterization of common pathways, occurring across multiple cases in our sample. 


\section{RESULTS}

\section{Characteristics of the reviewed cases}

The sample of 169 studies reviewed utilized a range of research approaches to both IPLCs' well-being and conservation effectiveness (Fig.1a and 1b). The well-being of IPLCs was approached through what may be termed a holistic approach, including material, social, cultural, and institutional and/or relational aspects, in $37 \%(\mathrm{n}=63)$ of studies. Purely material aspects of well-being, primarily income or income generating activity, possession of a specific asset, or material poverty were the focus of $30 \%(n=51)$ studies. The other $33 \%(n=55)$ were classified as intermediate in their approach to well-being (Fig. 1a). Regarding conservation effectiveness, $32 \%(n=54)$ of the study sample assessed biophysical changes in land use or ecosystem processes or a specific aspect of biodiversity such as an increase in elephant abundance, $36 \%(n=61)$ assessed an aspect of human behavior directly impacting biodiversity or perceptions of biophysical change, and $32 \%(n=54)$ used a combination of biophysical and social observations (Fig. 1b). The number of studies addressing links between the well-being of IPLCs and conservation increased over time, with $75 \%$ of our sample $(\mathrm{n}=$ 127) published since 2010 (Fig. 1c).

Fig. 1. Characteristics of the 169 studies included in the review: (a) research approach to human well-being; (b) research approach to conservation effectiveness; and (c) years in which the studies were published.

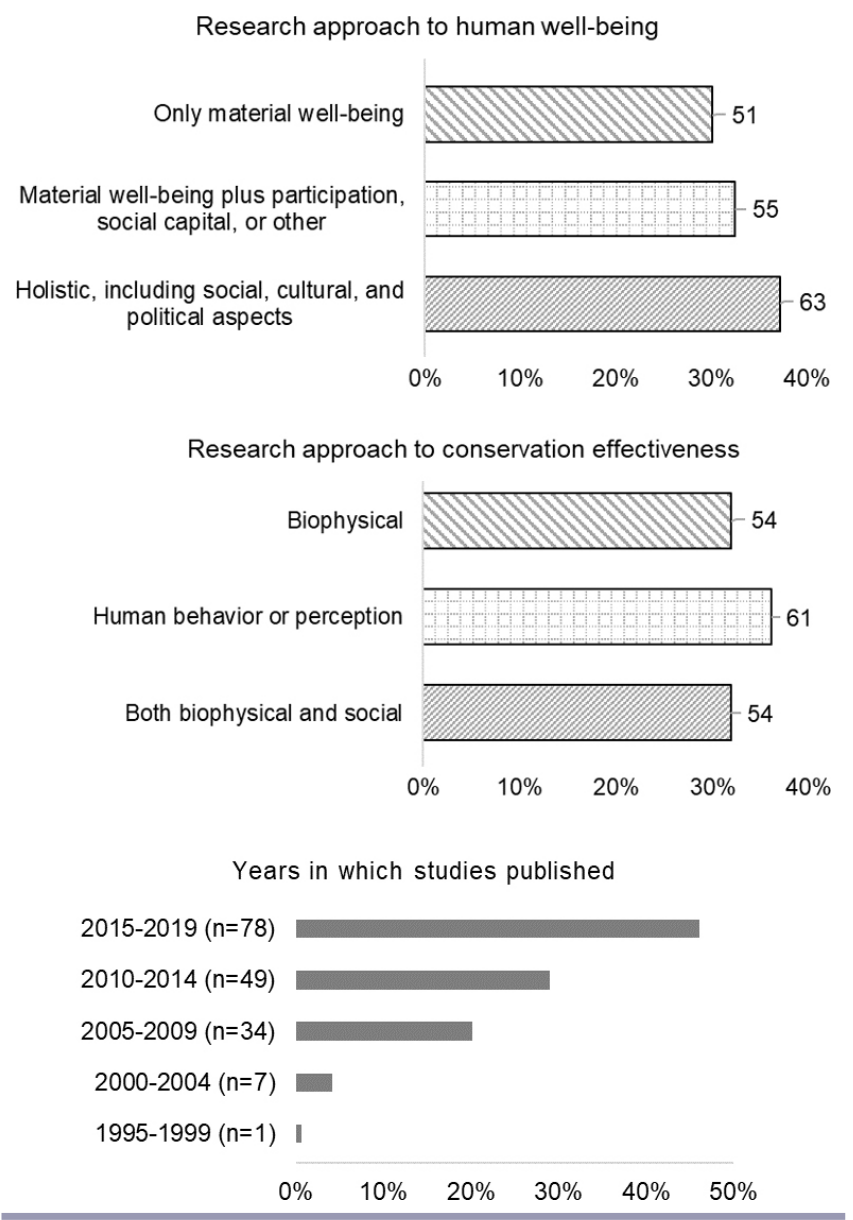

Figure 2 displays the 169 cases by governance arrangements, form of conservation, and ecosystem type. Fifty-nine studies (35\%) described conservation governance where communities held substantial power, ranging from autonomous territories or decentralized control (22 out of 59) to situations of shared governance where communities maintained responsibilities over parts of a land or seascape, or partnered with and were provided support by an external organization (37 out of 59 , Fig. 2a). The majority of cases $(60 \%)$ were categorized as "externally controlled" conservation interventions by state, nongovernmental, private actors, or a combination thereof (Fig. 2a). The remaining 8 cases $(5 \%)$ were categorized as externally controlled interventions, but for commercial purposes.

Fig. 2. Sample of 169 study cases categorized by (a) governance arrangements; (b) the form of conservation or land use; and (c) ecosystem type.

a) Governance arrangements

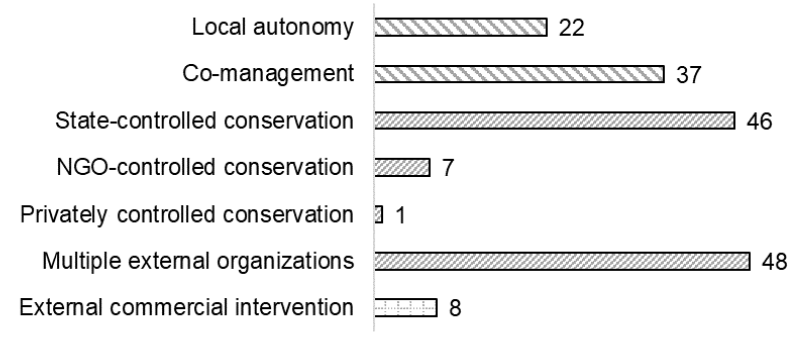

b)
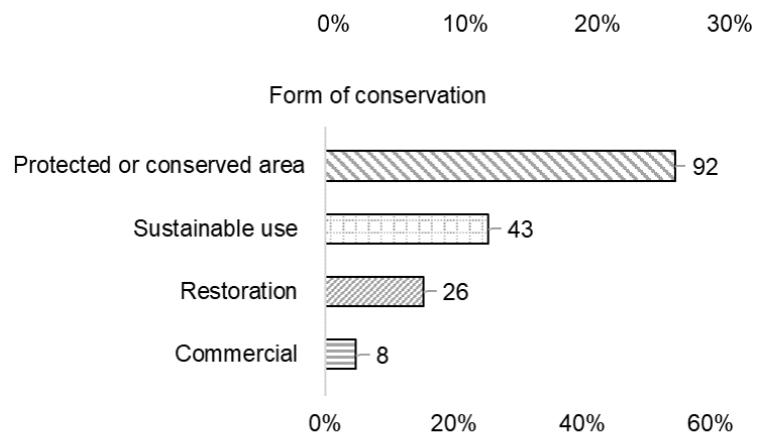

c)

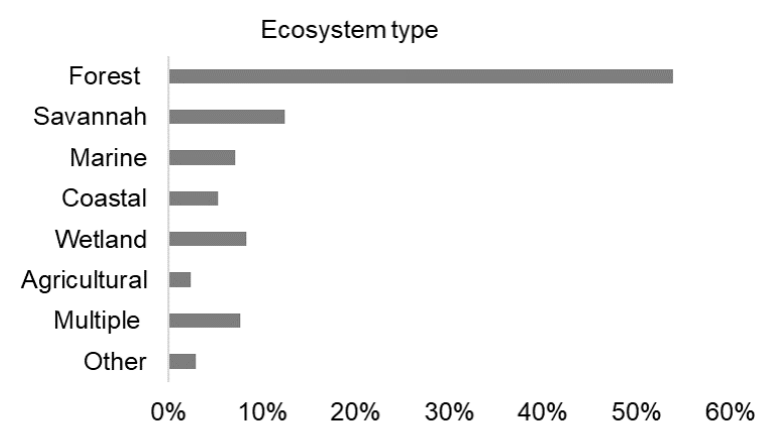

Figure 3 shows the geographic distribution of the 169 review cases with a broad spread across Africa (36\%), Asia (33\%), and Latin America (23\%), with only five or less cases from each of Europe, North America, Australasia, and Oceania. Therefore, geographic analysis focused on comparison of governance and dynamics among Africa, Asia, and Latin America. 
Table 1. Combinations of social and ecological outcomes reported in 169 published studies, categorized by externally controlled versus locally controlled governance approaches. IPLC = Indigenous peoples and local communities.

\begin{tabular}{|c|c|c|c|c|}
\hline & $\begin{array}{c}\text { Externally controlled } \\
\text { conservation } \\
\text { (as } \% \text { of } n=102 \text { ) }\end{array}$ & $\begin{array}{l}\text { Locally controlled } \\
\text { conservation } \\
\text { (as } \% \text { of } n=59 \text { ) }\end{array}$ & $\begin{array}{l}\text { Externally controlled } \\
\text { commercial land use } \\
\quad(\text { as } \% \text { of } n=8)\end{array}$ & $\begin{array}{l}\% \text { of total sample } \\
\qquad(\mathrm{n}=169)\end{array}$ \\
\hline Positive for IPLC well-being and conservation & 15.7 & 55.9 & 0.0 & 29.0 \\
\hline Negative for well-being and conservation & 34.3 & 3.4 & 25.0 & 23.1 \\
\hline Trade-off: Conservation positive, well-being negative & 17.6 & 3.4 & 0.0 & 11.8 \\
\hline Trade-off: Well-being positive, conservation negative & 2.0 & 8.5 & 25.0 & 5.3 \\
\hline $\begin{array}{l}\text { More complex outcomes (well-being and effectiveness affected } \\
\text { in multiple ways) }\end{array}$ & 30.4 & 28.8 & 50.0 & 30.8 \\
\hline
\end{tabular}

Fig. 3. Geographic distribution of the 169 cases. For countries with more than five cases, the numbers are presented in the map.

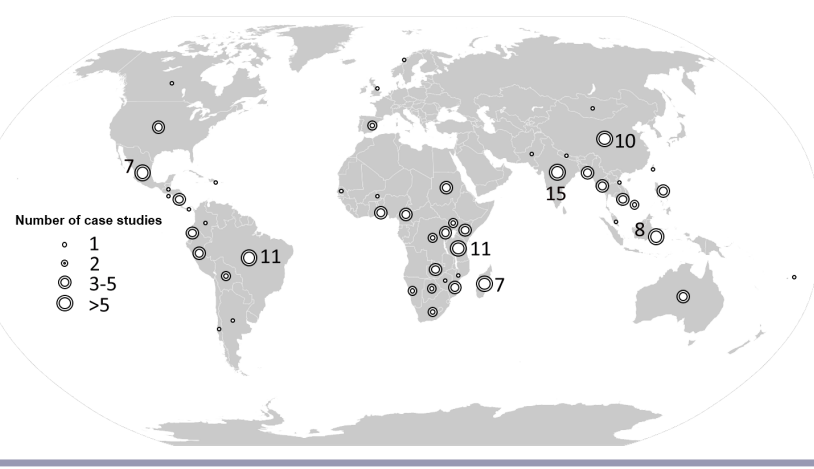

\section{Social and ecological outcomes associated with conservation governance}

The review data reveal a strong contrast between the social and ecological outcomes produced by externally designed and/or controlled conservation initiatives, and those more highly influenced by IPLCs (Table 1). With more than half of locally controlled cases $(55.9 \%)$ reporting positive social and ecological outcomes, a key finding of our analysis is that embedding local institutions in conservation governance more regularly leads to both enhanced well-being and positive conservation outcomes. This contrasts markedly with the 102 externally controlled interventions, of which only $15.7 \%(n=16)$ were evidenced by the authors as having produced positive social and ecological outcomes.

A second important finding is that negative outcomes for both well-being and conservation more commonly occur through topdown conservation governance, further highlighting its relative ineffectiveness. Of the 102 cases that were externally designed, controlled, or implemented, more than a third were reportedly associated with negative effects for both well-being and conservation (Table 1). This was 10 times the percentage of community-led cases exhibiting jointly negative outcomes and more than twice the proportion of externally controlled cases exhibiting concurrently positive social and ecological outcomes (Table 1).

To substantiate these findings, we examined whether the different social research approaches we identified were proportionately applied to different governance types (Table 2). We then explored the collective influence of each research approach on the social outcomes recorded in the publications' findings (Fig. 4). The different research approaches were relatively evenly applied to different forms of governance, except that a lesser proportion of studies focused solely on material well-being were applied to cases of locally controlled conservation governance (Table 2).

Table 2. Type of social research approach applied in the 169 reviewed studies to cases exhibiting different forms of governance.

\begin{tabular}{lccc}
\hline \hline & $\begin{array}{c}\text { Externally } \\
\text { controlled } \\
\text { conservation } \\
\text { (as \% of } \\
\mathrm{n}=102)\end{array}$ & $\begin{array}{c}\text { Locally } \\
\text { controlled } \\
\text { conservation } \\
\text { (as \% of } \\
\mathrm{n}=59)\end{array}$ & $\begin{array}{c}\text { Externally } \\
\text { controlled } \\
\text { commercial } \\
\text { land-use } \\
\text { (as \% of } \mathrm{n}=8)\end{array}$ \\
\hline $\begin{array}{l}\text { Material well-being only } \\
\begin{array}{l}\text { Intermediate approach } \\
\text { Holistic, including social, } \\
\text { cultural, and political }\end{array}\end{array}$ & 37.3 & 15.3 & 50.0 \\
aspects & 32.4 & 33.9 & 25.0 \\
\hline
\end{tabular}

Fig. 4. The proportion of the 169 reviewed cases characterized by (a) predominantly positive social outcomes; and (b) predominantly negative social outcomes, each displayed by social research approach applied and conservation governance type.

a) Cases associated with positive social outcomes

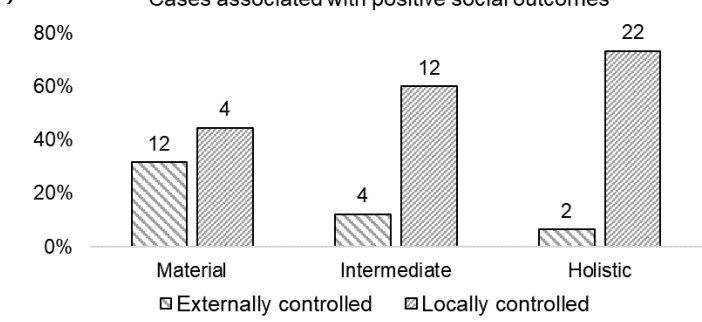

b)

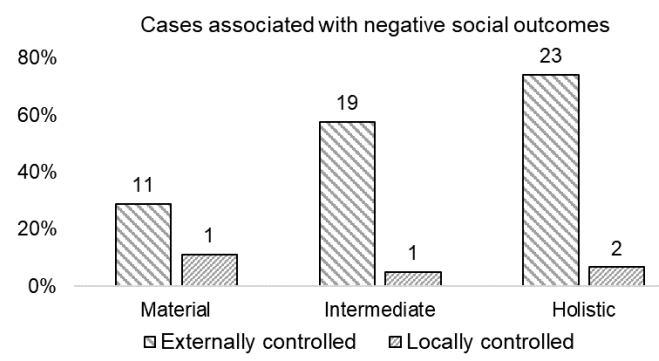


Table 3. Geographic distribution of the 169 cases presented in the reviewed studies and their key findings disaggregated by region.

\begin{tabular}{lccc}
\hline \hline & $\begin{array}{c}\text { Number of cases } \\
\text { \% of total } \\
\text { cases })\end{array}$ & $\begin{array}{c}\% \text { of cases featuring } \\
\text { locally led conservation }\end{array}$ & $\begin{array}{c}\text { \% cases reporting positive } \\
\text { outcomes for local well-being and } \\
\text { conservation }\end{array}$ \\
\hline Latin America & $39(23.1)$ & 53.8 & 41.0 \\
Africa & $60(35.5)$ & 28.3 & 25.0 \\
Asia & $56(33.1)$ & 23.2 & 21.4 \\
Oceania and Australasia & $5(3.0)$ & 60.0 & 60.0 \\
Europe & $4(2.4)$ & 50.0 & 75.0 \\
North America & $5(3.0)$ & 60.0 & 20.0 \\
Total/total average & $169(100)$ & 34.9 & 20.0 \\
\hline
\end{tabular}

Regarding the extent to which the social research approach influenced the types of social outcomes reported, predominantly positive social outcomes were recorded in similar proportions by studies focused only on material well-being $(35.3 \%$ of $n=51)$ and more holistic approaches that also considered social, cultural, and political aspects $(38.1 \%$ of $n=63)$. For the studies focused only on material well-being, the incidence of positive social outcomes was slightly lower for cases of externally controlled governance relative to locally controlled governance (Fig. 4a). However, this difference was much more pronounced for those studies applying holistic well-being approaches, or intermediate approaches, with positive social outcomes recorded in a far greater proportion of cases of locally controlled conservation relative to externally controlled conservation (Fig. 4a). Of the 59 studies reporting overwhelmingly negative social outcomes, $89.8 \%$ related to cases of externally controlled governance. The likelihood of recording negative social outcomes associated with externally controlled governance varied greatly with the social research approach applied, ranging from less than a third of studies focused on material well-being to almost three-quarters of those applying holistic approaches (Fig. 4b). Overall, these relationships suggest that many of the interactions between conservation and IPLCs are non-material and that inattention to the social, cultural, and political aspects of their well-being in any assessment may produce quite different findings, and potentially misleading recommendations, about conservation governance.

Trade-offs were recorded in $17.1 \%$ of cases overall $(n=29)$, most commonly involving positive conservation outcomes associated with negative well-being outcomes through externally controlled conservation interventions (18 cases, $10.7 \%$ of total sample). More complex sets of outcomes occurred in $30.8 \%$ of all cases, meaning that well-being and/or conservation were impacted in multiple, conflicting ways, and both could not, therefore, be characterized simply as positive or negative. A common example involved unequal social impacts from market-oriented conservation interventions, with some local people benefitting while others suffered. Similarly, biodiversity was in some cases shown to benefit from stricter regulation of resource use, though concurrent commercial development or human-wildlife conflict sometimes counteracted those gains. The likelihood of recording complex outcomes increases with the extent to which well-being or effectiveness were disaggregated in each study, either into constituent parts or across people and species. However, the incidence of complex outcomes was not skewed toward a particular form of governance, with $30.4 \%$ of cases of externally controlled conservation exhibiting complex outcomes versus $28.8 \%$ for cases under local control (Table 1).

Regarding geographical differences in the findings, Table 3 shows the proportion of cases of locally controlled conservation was higher in Latin America (54\% of 39 cases) relative to Africa (28\%) and Asia $(23 \%)$. Notably, this also translated into a higher proportion of cases reporting concurrently positive social and ecological outcomes from Latin America (Table 3). Indeed, 14 of the 15 Latin American cases reported to produce positive synergies were the result of locally led forms of conservation governance, spanning across 10 different countries.

\section{Pathways linking forms of conservation governance with combinations of social and ecological outcomes}

Our analysis of the dynamics through which forms of governance are associated with certain combinations of social and ecological outcomes yielded six types of pathways, which were consistent across geographic and political contexts and across intervention types.

\section{Empowered local communities as a primary pathway to effective conservation}

Overall, $29.0 \%$ of studies provided evidence of simultaneous positive social and ecological outcomes, with more than twothirds (33 out of 49 cases) associated with local control and stewardship (Table 1). These cases underscore that the most important social factors supporting attainment of positive conservation outcomes are not the magnitude of material benefits that IPLCs attain, but rather the recognition of local social and cultural practices, and the ability of those communities to influence decision making (Bawa et al. 2007). Local institutions governing land, sea, and natural resources are entwined with social relations and cultural and spiritual expression, and have often evolved in the face of environmental constraints to deliver both a good quality of life (Diemont and Martin 2009) and effective, long-term conservation (Terer et al. 2012). Figure 5 illustrates the central role played by IPLCs in effective conservation. The figure shows the complex pathways through which certain governance qualities may support IPLCs' wellbeing and, in the presence of certain enabling social and institutional attributes at the local scale, and political and legal conditions at wider scales, can empower the environmental stewardship actions that produce effective conservation.

Local institutions and resulting stewardship efforts are reported to effectively conserve biodiversity through several actions or capacities: sustainable self-regulation of resource use (Apgar et 
Fig. 5. The central and inseparable role of Indigenous peoples and local communities in equitable and effective biodiversity conservation.

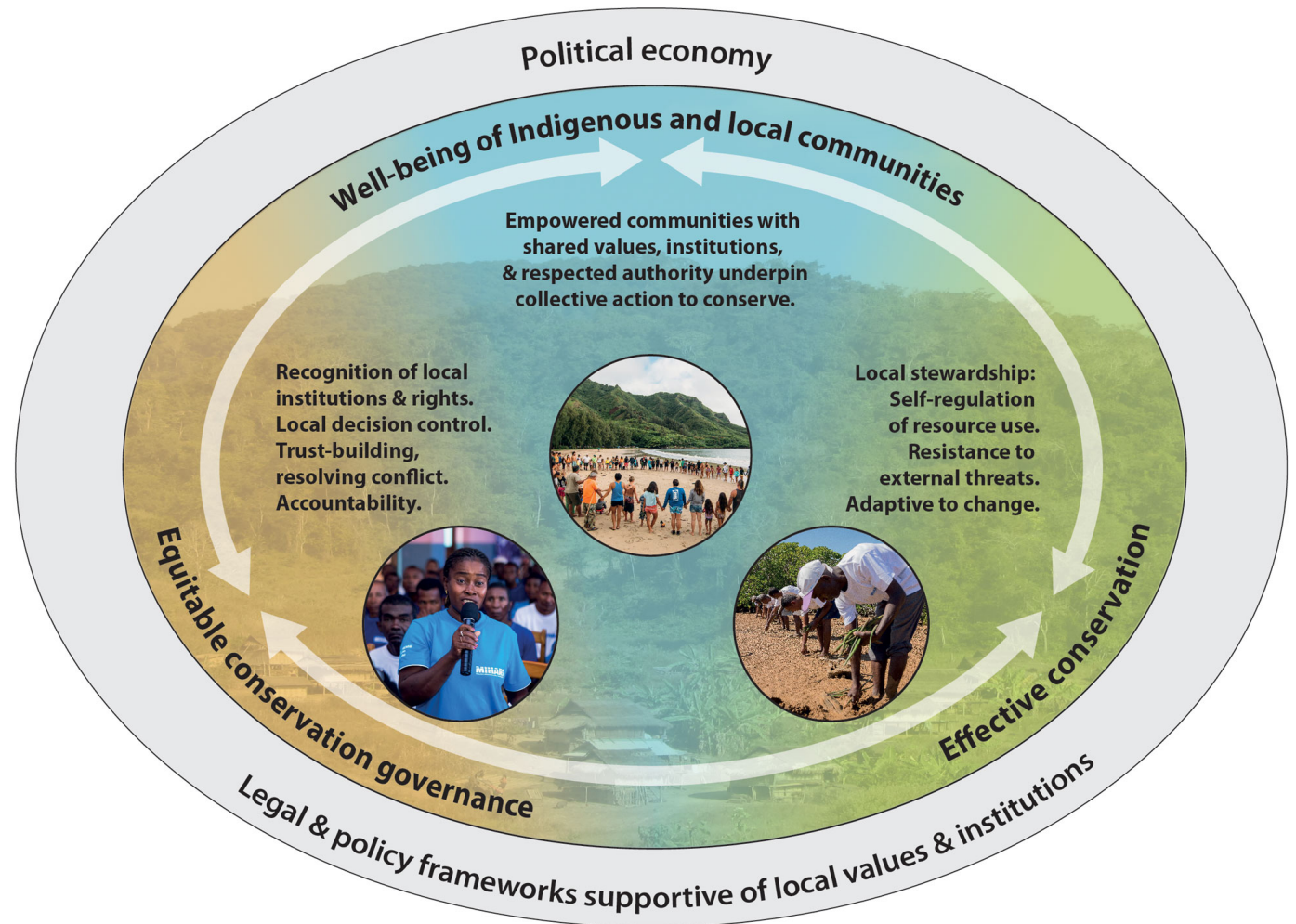

al. 2011); concerted habitat restoration (de Souza et al. 2016); the assertion of collective territory to prevent encroachment and resist external commercial and extractive pressures (CamposSilva et al. 2018); and the ability to maintain or adapt conservation institutions and stewardship practices in the face of environmental, economic, or political change (Nyirenda et al. 2018). For example, in Taiwan, an Indigenous Tsou village restored a degraded state-run national forest by collectively and voluntarily self-regulating resource use and by resisting external commercial pressures; by doing so, they gained secure tenure as legitimate forest stewards (Tai 2007). In Nepal, effective stewardship of a riparian habitat was enacted by low-income communities through the development of new local conservationoriented institutions (Bunch 2016). Degradation and environmental hazards provided motivation, while collective leadership and inclusive processes further enabled the creation of sustainable sanitation facilities, community gardens, and a biogas plant to overcome previously life-threatening waterborne human and livestock diseases. These same features of social organization and place-based connections between social identity and biodiversity may also drive stewardship in wealthier contexts: in the United Kingdom, a community of stewards developed among farmers to promote wildflower diversity even in contradiction of prevailing commercial norms (Saxby et al. 2018).

A number of non-local institutional factors enabled community efforts. One key factor for success in many cases was the quality of inter-institutional collaboration and relationships (Arambiza and Painter 2006). Relationships of trust were a prerequisite for community mobilization that in many cases had to be developed over time through conflict resolution processes, transparent and timely communication, intercultural understanding, and respect for local rights. These factors are exemplified by research into a co-managed watershed restoration program in the Democratic Republic of the Congo, where the establishment of mixed gender leadership through legitimate local institutions was deemed a key success factor (Sabin et al. 2019).

Optimally, local ecological knowledge should not only have relevance to village-level governance, but should be recognized in law and policy and integrated across scales of governance. In northern Norway, Indigenous Saami fishers raised alarms about the ecological risks of fish farming to wild marine stocks and, when scientific research supported their claims, their knowledge enabled swift decision making to prevent fishery collapse (Brattland 2013). As a result, the value of traditional ecological knowledge gained recognition and the Saami were afforded permanent influence in national governance processes.

\section{Political and legal structures often fail to recognize local institutions}

We found that national legislative frameworks and policies often failed to recognize local institutions or to secure tenure rights, in many cases to the detriment of IPLCs' traditional ecological knowledge, customary practices, and associated livelihoods. Twenty-five cases $(14.8 \%$ ) were characterized by locally controlled 
conservation governance that does not achieve positive outcomes for well-being and conservation. When we examined the factors reported to have influenced those outcomes, we found that, even in the absence of externally controlled conservation interventions, policies and interactions with the state and other external actors nevertheless often presented obstacles. Instead of supporting IPLCs and empowering active stewardship (as reflected in Fig. 5), wider policies and discourses frequently served to dismantle local institutions, disempower and sever locals from their conservation-based practices, and actively promote unsustainable exploitation of ecosystems (Adjei et al. 2017). To overcome these challenges, and the social and environmental harms they bring upon IPLCs and their territories, communities must often mobilize to defend their rights and organize multi-scale coalitions against powerful actors and (often long-term) injustices. For example, although the Indigenous Yurok eventually gained territorial autonomy in California through coalitions and court proceedings, long-term discrimination against them had eroded forest management institutions, while gold mining and timber extraction caused forest loss and fragmentation, necessitating efforts to revitalize cultural practices and rebuild capacity to restore the ecosystem (Huntsinger and Diekmann 2010).

For many cultural minorities, past negative experiences of social and environmental policies mean trust-building or conflict resolution processes may be necessary foundations for collaborative conservation efforts. Timely communication, transparency, and accountability are important aspects of governance that can support collaboration and enable trajectories toward enhanced conservation effectiveness (Kideghesho 2008). However, lack of recognition of customary and communal tenure arrangements is often a central issue shaping past injustices and in the contemporary negotiation of conservation partnerships and structures, particularly where externally promoted individual property rights risk producing insecure tenure rights for the most vulnerable (Nayak et al. 2014).

\section{Imposed conservation suffers weak legitimacy that can trigger local resistance}

The cases describing combined negative social and ecological outcomes arising from externally controlled conservation governance (Table $1 ; \mathrm{n}=35$ or $21 \%$ of total sample) outline a pathway with the opposite dynamics to the synergistic scenario shown in Figure 5. This set of cases primarily features protected areas that restrict access and provide little opportunity to influence regulations, while pushing IPLCs toward alternative livelihoods. Collectively they sketch a consistent pathway characterized by extreme restrictions set by external actors that are rendered unimplementable by a combination of insufficient resources, governance weaknesses, social diversity, and unequal power relations, negative social impacts, and consequent forms of local resistance (Mwakaje et al. 2013, Vergara and Barton 2013). For two different cases in India, researchers found that governance weaknesses such as low accountability can lead to various forms of corruption, which, alongside the displacement of local institutions, opens the door to land and resource grabs, especially where conservation is poorly financed (Rawat et al. 2010, Chhotray 2016).

Impacts leading to diminished well-being or perceived injustices associated with top-down conservation governance are often reported to lead to local resistance or actions by IPLCs to defend their territories. This resistance may be expressed in many forms and over long timescales, but commonly obstructs the theory of change envisaged by the controlling external organizations to realize effective conservation. In Zambia, a state-run game management area relied on commercial hunting for revenue while prohibiting hunting by IPLCs and excluding them from decision making (Lindsey et al. 2014). Consequently, the imposed rules were perceived to have little legitimacy, leading to lack of rule compliance, high levels of local hunting for bushmeat, and lack of effort by IPLCs to limit unsanctioned hunting and other uses by external actors. In the Dominican Republic, the severity of livelihood impacts produced by a strictly protected area were initially met by coordinated complaints through formal petitions, but the lack of response to these official channels triggered violent reprisals by local community members (Holmes 2014). The rules were perceived to be so harmful to IPLCs that they eventually lost legitimacy among park guards, who allowed local access to go unreported, thus establishing an alternative, informal layer of governance. At a Mexican Biosphere Reserve, a scheme to compensate for livestock depredation by predators was perceived to be non-transparent, exclusive, and unfair, resulting in increased retribution killings of jaguars as local farmers lost faith in the scheme (Lecuyer et al. 2018).

This set of studies again emphasize how externally controlled conservation interventions may be aligned with other external pressures that discriminate against, dispossess, and attempt to culturally assimilate IPLCs, sometimes violently. For example, a study from Minas Gerais, Brazil describes how policies expelled IPLCs from their ancestral territories in the 1980s as part of development programs and later displaced the same communities again when protected areas were established to address degradation caused by the initial development programs (Anaya and Espírito-Santo 2018). Despite this, local people tend still to be strongly pro-conservation there but were motivated to act against the imposed forms of governance that they did not see as legitimate.

\section{Imposed conservation can be ecologically effective but at great social and financial cost}

Overall, a third of the 102 cases of externally controlled conservation governance were reported to produce positive ecological outcomes. Sixteen were presented as positive for both well-being and conservation, while the other 18 brought social costs for IPLCs, representing a common form of trade-off (Table 1). Conservation interventions controlled by external organizations tend to be better financed, administered, and enforced, potentially resulting in more likely attainment of some conservation goals. However, the underlying power imbalances and social conflicts arising in many of those cases still raise questions as to how durable and socially acceptable these forms of governance are. For example, four cases reported as having positive outcomes comprised resettlement of communities. Among them was the Derema Corridor in Tanzania, where negative social outcomes were found to outweigh any positives, while disproportionate harm was caused to women and the most vulnerable (Hall et al. 2014). Those harms occurred despite high levels of funding and the application of the World Bank's resettlement safeguards by several large international NGOs (Hall et al. 2014). In a successful Namibian conservancy, reliant 
on trophy hunting and tourism revenue, local pastoralists claimed to have become slaves because of damage caused to water sources and their sudden dependency on scarce laboring opportunities now in the control of private owners (Schnegg and Kiaka 2018).

When scrutinized, the majority of the 16 cases presented as positive for both biodiversity and IPLCs (Table 1) appear to entail trade-offs similar to those described above rather than showcasing best practices. Ten of those 16 studies applied material well-being definitions focused only on income, wealth, or assets. Attention solely to material well-being may lead to potential oversight of non-material impacts (Fig. 4), including place and livelihood detachment, food or tenure insecurity risks, deteriorating social relations or the emergence of conflict, and the loss of cultural practices, which may disproportionately harm vulnerable social groups (Xu et al. 2009, Celentano et al. 2014). For example, a case presented as positive for both well-being and conservation involved the relocation of communities by the Chinese State to allow for forests to regenerate, which, eventually, they did (Cao et al. 2017). The communities were offered incentives to take up alternative livelihoods, often involving migration to urban areas, which was concluded to have enhanced people's income-earning potential. However, the study's economic-oriented assessment accorded little credence to local perceptions or non-material impacts, suggesting that numerous forms of social harms that would alter interpretations of the program's success may have been overlooked.

\section{Market-oriented conservation produces social exclusion and perverse incentives}

Thirty-one cases of market-oriented conservation interventions were included in our sample $(18.3 \%)$, comprising payment for ecosystem service projects, reduced emissions from deforestation and forest degradation (REDD+) programs, alternative livelihood programs, and certification schemes. These models represent increasingly prominent forms of conservation intervention (Jones et al. 2018). Although the governance associated with these interventions is often described in studies or by conservation organizations as "community-based" resource management, closer analysis of the extent of local influence and the roles of local institutions led to all 31 cases being categorized as "externally controlled." Private companies rarely controlled these interventions single-handedly, as NGOs and state agencies also held influence in almost all cases.

These cases consistently provide evidence that material benefit alone is rarely sufficient as a pathway to compensate or motivate IPLCs to align with conservation regulations. In the rare case that programs are well-funded enough that revenue flows to local communities, and that governance functions effectively, positive outcomes may result: seven cases were presented as positive for both well-being and conservation. However, negative social outcomes for some, if not all, affected community members were recorded in $74 \%$ of this set of cases. Addressing social heterogeneity and avoiding any harm associated with an intervention is undeniably challenging. However, our synthesis reveals that market-oriented conservation interventions often generate adverse effects for considerable proportions of affected communities by neglecting to tailor development projects to local livelihoods and social dynamics. Nor do such interventions typically support or strengthen local governance systems that aim to tackle unequal benefits or harms arising in a culturally appropriate manner. For example, in a case in the Philippines, an agricultural development program aimed at diverting livelihoods away from forests ended up harming local communities as it failed to account for local strategies to cope with vulnerability to scarcity and for customary tenure systems (Dressler et al. 2016). Other cases show market-oriented conservation benefiting the most well-off and powerful community members. In the Mkuze Wetlands, South Africa, a minority gained additional income from a conservation and development initiative, while community members most dependent on the wetland resources saw their access rights curtailed without options to redress the impacts suffered (Dahlberg and Burlando 2009).

The reliance on external private companies to provide reliable, consistent benefit flows and to minimize environmental impacts, may be vulnerable to a variety of things, including instances of insecurity, economic shock, health crises, environmental hazards, and funding changes. For example, Cooper and Kainer (2018) detail how, at an extractive reserve in Acre, Brazil, power was transferred to timber companies because traditional timber extraction methods were deemed unprofitable. However, weak accountability and rising financial incentives meant the companies swiftly began overharvesting. The eight cases featuring externally controlled interventions purely for commercial mining, forestry, and agriculture rather than conservation purposes (Table $1 ; 4.7 \%$ of the 169 cases) produced more unequal and severe outcomes. Although providing short-term material gains for external actors and local elites, the rapid ecosystem degradation they instigated at these resource frontiers soon generated substantial harms to local well-being (e.g., Hossain et al. 2017, Antwi et al. 2017).

\section{Turning losses into wins: transitions in governance to enhance equity and rights}

Of the 16 cases of externally controlled conservation presented as positive for both well-being and conservation, four provide replicable governance lessons. In each, IPLCs mobilized cohesively to support the conservation intervention because an opportunity arose for enhanced participation, recognition, or access to a form of benefits. For a case in Botswana, researchers describe how a trophy hunting program provided transparency and immediate monetary benefits as well as influence for IPLCs over their allocation (Mbaiwa 2011). The other cases described progressive transitions away from externally controlled, restrictive, and exclusive conservation toward a situation of cooperation between communities and conservation organizations. This facilitated a more central role in governance for communitylevel institutions, leading to improved, if not entirely positive outcomes. At a Ramsar site in Ghana, regulations evolved to tolerate local sustainable use of wetland resources, aligning more with local perceptions of fairness and realizing enhanced compliance, even if local influence remained low (Agyare et al. 2015). In Kenya, a REDD+ project was adapted to recognize communal forests, enabling greater inclusion of vulnerable people otherwise lacking land access and unable to participate (Atela et al. 2015). Formal recognition of local practices and institutions, such as systems of communal forest management, can represent transitions in governance that raise perceptions of legitimacy among IPLCs and increase the potential for more equitable and effective conservation. 
Table 4. Summary of the main pathways identified through this review linking types of conservation governance with the well-being of Indigenous peoples and local communities (IPLCs) and conservation effectiveness, along with key insights for conservation practice.

\begin{tabular}{|c|c|c|}
\hline $\begin{array}{l}\text { Pathway linking well-being of } \\
\text { IPLCs with conservation } \\
\text { effectiveness }\end{array}$ & $\begin{array}{l}\text { Evidence from this review, associated intervention types, and } \\
\text { influential factors at local or wider scales }\end{array}$ & $\begin{array}{l}\text { Key insights for practice to enhance conservation } \\
\text { effectiveness and IPLCs' well-being }\end{array}$ \\
\hline $\begin{array}{l}\text { 1. Empowered local } \\
\text { communities effectively conserve } \\
\text { nature through stewardship }\end{array}$ & $\begin{array}{l}\text { Across various contexts, positive social and ecological } \\
\text { outcomes are primarily associated with locally controlled } \\
\text { governance, where IPLCs' rights and institutions are } \\
\text { recognized. When supported by policy, law, and external } \\
\text { organizations this empowers collective stewardship. }\end{array}$ & $\begin{array}{l}\text { Whether for restoration, sustainable use, or area-based } \\
\text { conservation, from biodiversity hotspots to degraded } \\
\text { urban habitats, local institutions should be at the center } \\
\text { of conservation governance. Make this a key assessment } \\
\text { criteria for good governance. }\end{array}$ \\
\hline $\begin{array}{l}\text { 2. Political and legal structures } \\
\text { fail to recognize local } \\
\text { institutions }\end{array}$ & $\begin{array}{l}\text { Lack of recognition in law, policy, and by relevant external } \\
\text { organizations often impedes IPLCs from achieving positive } \\
\text { outcomes, even with locally controlled conservation } \\
\text { governance. }\end{array}$ & $\begin{array}{l}\text { Foster stewardship by IPLCs, establish processes to } \\
\text { address barriers and resolve conflicts, particularly } \\
\text { against commercial development, discrimination, or } \\
\text { rights violations. }\end{array}$ \\
\hline $\begin{array}{l}\text { 3. Imposed conservation suffers } \\
\text { weak legitimacy that can trigger } \\
\text { local resistance }\end{array}$ & $\begin{array}{l}\text { Negative social and ecological outcomes overwhelmingly } \\
\text { associated with external governance control, especially } \\
\text { exclusive protected areas in tandem with development } \\
\text { interventions. Their objectives are often unachievable, } \\
\text { especially because of a lack of congruence with IPLC values. }\end{array}$ & $\begin{array}{l}\text { Involve IPLCs from the start as part of solutions. } \\
\text { Understand their values, institutions, and potential } \\
\text { contribution, not just economic impacts of external } \\
\text { predefined conservation and development strategies. }\end{array}$ \\
\hline $\begin{array}{l}\text { 4. Imposed conservation can be } \\
\text { ecologically effective but at great } \\
\text { social cost }\end{array}$ & $\begin{array}{l}\text { Externally controlled, highly resourced conservation can be } \\
\text { effective for biodiversity but often produces unacceptable } \\
\text { social harms that bring long-term success into question. }\end{array}$ & $\begin{array}{l}\text { Conduct and act upon broad social assessment in } \\
\text { advance of and during conservation interventions, } \\
\text { including establishing and applying safeguards relating } \\
\text { to rights, customary institutions, and social, cultural, } \\
\text { and political aspects of well-being. }\end{array}$ \\
\hline $\begin{array}{l}\text { 5. Market-oriented conservation } \\
\text { produces social exclusion and } \\
\text { perverse incentives }\end{array}$ & $\begin{array}{l}\text { Material compensation is rarely sufficient to align IPLCs with } \\
\text { conservation regulations. Local institutions can be important } \\
\text { to support social inclusion, avoid harms, and to empower } \\
\text { communities. }\end{array}$ & $\begin{array}{l}\text { Market-oriented interventions in particular should } \\
\text { consider non-material impacts and the importance of } \\
\text { local customary and communal institutions to promote } \\
\text { more inclusive, locally acceptable programs. }\end{array}$ \\
\hline $\begin{array}{l}\text { 6. Transitions in governance to } \\
\text { enhance equity and rights }\end{array}$ & $\begin{array}{l}\text { Social or ecological failures can be turned around through } \\
\text { dialogue and collaborative efforts to improve governance, } \\
\text { address harms, and align values and interests. }\end{array}$ & $\begin{array}{l}\text { Establish governance as an interactive, ongoing } \\
\text { collaborative transition toward enhanced equity and } \\
\text { promoting actions that underpin effective conservation. }\end{array}$ \\
\hline
\end{tabular}

\section{DISCUSSION}

\section{Implications for how to conserve nature and support local well- being}

As world leaders renew their pledges to reverse the decline in biodiversity, expansion of the proportion of land and seas under formal protection is still promoted as the flagship strategy to tackle biodiversity loss and ensure human well-being (Vaughan 2020). However, based on the literature examining the socialecological outcomes most often associated with conservation governance, we find that positive outcomes for both nature conservation and the well-being of local communities are not often realized. These findings mirror those of Howe et al. (2014), where an analysis showed trade-offs between ecological and social outcomes to be three times more likely to be reported than positive synergies. The lack of attention to governance quality generally damages both the well-being of IPLCs and the capacity to tackle biodiversity loss (Lockwood 2010, Tauli-Corpuz et al. 2020). Our global synthesis of peer-reviewed evidence underlines how interventions controlled by external organizations based on logics that do not acknowledge the inextricable connection between IPLCs' livelihoods and biodiversity, and instead seek to supersede local practices and customary institutions, tend to result in relatively ineffective conservation. In contrast, this review adds to growing evidence that, when the legislative and policy arrangements are supportive, equitable governance that recognizes local knowledge and institutions, and serves to empower and support the environmental stewardship of IPLCs, represents the primary pathway to effective long-term conservation of biodiversity (Fig. 5, Table 4).

\section{Good governance and effective conservation are inextricably connected}

If we are to address the underlying causes of biodiversity loss, governance quality must become a more prominent policy objective. Good governance comprises clear respect for local rights and institutions, decision-making influence for IPLCs, and accountability to adhere to these standards (Ostrom et al. 1999, Brosius 2004, Borrini-Feyerabend et al. 2013, CBD 2018). Evidence consistently reveals that social, cultural, and relational effects of conservation governance eclipse financial benefits in driving social and ecological outcomes (Palmer et al. 2020, Thondhlana et al. 2020). Furthermore, our findings emphasize governance as an ongoing process of negotiated interests. Good governance can therefore be viewed as a collaboratively shaped trajectory toward both social and ecological goals, including enhanced equity and rights for IPLCs and responsibilities for actions to attain them (Folke 2004, Dawson et al. 2018, Pereira et al. 2018). Governance quality (encompassing how authority is exercised and how fair, transparent, and accountable processes are) is a more appropriate objective than governance diversity (who holds authority) because although governance diversity has gained some policy traction within the $\mathrm{CBD}$, it implies that externally controlled interventions that exclude IPLCs should persist in some cases rather than transition to more equitable forms (Gannon et al. 2019).

An emphasis on culturally appropriate and locally led conservation governance goes further than standards of community engagement currently articulated in many conservation policies and programs, such as "full and effective 
participation" or "respect for traditional knowledge" (Schreckenberg et al. 2016). It demands attention to IPLC's potential contributions to conservation, as well as to a range of social and cultural harms and impacts to diverse people. Our findings relate to many of the goals and targets in the CBD's draft global biodiversity framework for the decade to 2030, but are perhaps most relevant for the target focused on the incorporation of traditional knowledge for the effective management of biodiversity and the target aiming to "ensure equitable and effective participation in decision-making related to biodiversity by indigenous peoples and local communities, and respect their rights over lands, territories and resources, as well as by women and girls, and youth" (CBD 2021). In particular, our findings underscore the need to identify, integrate, and support customary systems of tenure and authority rather than overlaying them with entirely different structures. We recommend that governance assessment of any conservation initiative, including nature-based solutions, incentive schemes or conserved areas, require reporting on the national and subnational approach to local practices and institutions, with specific attention to customary and communal tenure regimes and rights. Although recognition of customary tenure and rights is politically sensitive in many countries, we show inattention to it to be damaging to conservation. Indeed, a shift toward more equitable governance and recognition of the rights of IPLCs reflects greater adherence to internationally accepted governance standards and law rather than a revolution fraught with risk.

Recognition of local institutions, knowledge, and tenure rights produces effective conservation when it empowers collective local environmental stewardship (Fig. 5). However, effective stewardship depends on a number of enabling social and political factors, in the absence of which positive social and ecological outcomes are unlikely to result. At the local level, these include shared values, community cohesion, respected institutions, and good leadership. At wider scales enabling factors include trust, cooperation, and capacity of external organizations alongside supportive legal and political structures. In a few contexts, these factors coincide. As a complete example of these dynamics, Dearden et al. (2017) detail how a community at Koh Pitak Island in Thailand mobilized to restore mangrove and reef habitats, introduce sustainable waste management, regulate fish-catches spatially and seasonally, and develop culturally appropriate forms of tourism enterprise. Such stewardship was facilitated locally through progressive leadership, close social ties, and norms for equitable distribution, and at wider scales through media interest, community networks, good relations with state agencies and universities alongside national policies promoting decentralization and self-sufficiency.

In many circumstances, legal and institutional empowerment and support for local institutions is lacking. Although active displacement of cultural minorities from ancestral lands may not be considered an acceptable means to conserve in global policy norms, it is still a quite common practice globally through neoliberal strategies involving strict protection of resources alongside commercialization of livelihoods (Chiaravalloti 2019, Otero et al. 2020). "Green grabbing" and "blue grabbing," the acquired control of lands and oceans by external actors for the purposes of conservation, to the detriment of local communities, is still regularly recorded in restoration, conservation, and development programs (Franco and Borras 2019). In this sense, our recommendation for greater recognition of and power to IPLCs is not only pertinent for efforts addressing global biodiversity loss (Tauli-Corpuz et al. 2020), but is also consistent with calls to decolonize conservation (Büscher and Fletcher 2019) and protect environmental human rights defenders (Scheidel et al. 2020, Larsen et al. 2021).

Putting Indigenous peoples and local communities at the center of conservation

Any shift toward a greater role for local institutions in conservation governance must involve acknowledgement and deliberation of past processes and injustices that have shaped the current local social, ecological, and political situation (Madden and McQuinn 2014, Rodriguez 2017). Although conflictresolution processes can be time intensive, guidance and tools have been effectively trialed and developed (Freudenthal et al. 2012, Dhiaulhaq et al. 2015). Increased focus on intercultural understanding, trust-building, technical and legal capacity building may necessitate external actors directing effort away from activities such as relocation, re-education, and alternative livelihoods. State agencies, NGOs, and private organizations still clearly have a role to play in conservation, yet that may be constructively reoriented to facilitation, supporting local capacity and bridging to wider scales of governance (Berkes 2009). In the long run, such changes can present cost-effective models of governance that deliver multi-fold benefits for nature as well as the public, governments, and private agencies (Larson 2003), and can be highly durable and adaptable in the face of external pressures (Wilson 2012). In contrast, externally controlled governance models can be vulnerable when tied to international funding, subject to political trends (Massé and Margulies 2020) or impacted by shocks such as the coronavirus pandemic, which saw tourism revenue plummet (Lindsey et al. 2020).

Most constructively, local social-ecological knowledge should be integrated into higher levels of decision making, beyond the community, and into governance at national and even international levels alongside scientific understanding (Folke 2004, Díaz-Reviriego et al. 2019). Latin America provides many of the examples to date of socially progressive conservation governance because decentralization processes were prominent across the region beginning in the 1990 s and served to increase the recognition of local institutions (Larson 2003). Locally led efforts may also be supported by large-scale networks to share experiences and best practices, as exemplified by the Indigenous peoples' and Community Conserved Territories and Areas (ICCA) Consortium's work to gain recognition of communityled efforts within the global database of conserved areas (Tran et al. 2020).

\section{Future research}

There is a need to look more deeply at conservation practice, and engrained assumptions about why and how to conserve, through combined analysis of conservation effectiveness, IPLCs' wellbeing (including non-material aspects), and their interdependence (Ban et al. 2019). Our findings endorse that research approaches applied to conservation must, at a minimum, be appropriately designed to explore IPLCs' knowledge, institutions, and the viability of local stewardship of the environment as a pathway to sustainability (Cumming et al. 2020). Integrating social 
dimensions to conservation science requires considering not only the economic impacts on communities, but also efforts to elicit a broader understanding of well-being (and potential harms) from among the range of interrelated social, cultural, economic, environmental, and political values, experiences, causes, and impacts (Biedenweg and Gross-Camp 2018, Gill et al. 2019). Although embracing such complexity may sound unrealistically demanding, considerable progress has already been made in this direction with many frameworks, e.g., for well-being, environmental justice, social-ecological resilience, and biocultural approaches, and associated tools are now available to facilitate interdisciplinary research and its integration to conservation and development practice (Sikor et al. 2014, Bennett et al. 2017, Sterling et al. 2017, Loveridge et al. 2020). This rapid shift toward more inter-or multi-disciplinary conservation research is reflected by our sample including only a single study published prior to 2000, a shift also recorded in similar syntheses (McKinnon et al. 2016). Looking beyond conservation science, state of the art impact assessments employ rigorous study designs adequate to robustly identify causal pathways, which few from our sample did. Future advances to overcome design weaknesses might employ complementary quantitative or qualitative approaches, individually or in combination through mixed-methods designs, including statistical matching to control for confounding drivers of change (Ferraro and Hanauer 2015, Schleicher et al. 2020).

\section{CONCLUSION}

Plans to greatly expand the conserved area of land and sea threaten to harm already marginalized people and may fail to effectively conserve nature. There is increasing understanding of what types and qualities of governance work for people and for biodiversity in the face of complex social, ecological, and institutional dynamics and growing evidence that IPLCs have a key role to play as stewards of the environment (BorriniFeyerabend et al. 2013, Oldekop et al. 2016, Garnett et al. 2018, Reyes-García et al. 2019). Our synthesis details how conservation governance that provides greater control to IPLCs and supports local environmental stewardship is a primary pathway to effective biodiversity conservation. This is crucial in the current debate among conservation policy makers regarding how to effectively conserve biodiversity at the same time as supporting the wellbeing and rights of IPLCs, for instance in the negotiation and subsequent implementation of the CBD 2030 goals and targets.

Responses to this article can be read online at: https://www.ecologyandsociety.org/issues/responses. php/12625

\section{Acknowledgments:}

We are thankful for funding and support provided by the International Union for the Conservation of Nature Commission on Environmental, Economic and Social Policy (IUCN CEESP), particularly the Chair, Kristen Walker Painemilla, and Deputy Chair, Ameyali Ramos Castillo. We are grateful for advice and voluntary contributions provided by members of the CEESP Theme on Human Wellbeing and Sustainable Livelihoods and especially to
Grazia Borrini-Feyerabend for constructive comments. ND and BC were supported through the "Just Conservation" project funded by the Centre for the Synthesis and Analysis of Biodiversity (CESAB) of the French Foundation for Research on Biodiversity (FRB), https://www. fondationbiodiversite.frl. NGC's time was funded through the Darwin Initiative RESPeCT project (No. 25-019). We are grateful to Samantha Cheng at the American Museum of Natural History for her time and advice on use of Colandr software and to Andy Wright https://www.madebyawdesign.com/ for the illustration of Figure 5. For images in Figure 5 we thank: the MIHARI Network https://mihari-network.org/ who permitted use of images of a fisherwoman speaking and Mangrove reforestation at Belo-sur-Mer, southwestern Madagascar; and Holladay Photo for the image of the Kahana community, Koolauloa, Oahu doing a traditional Hawaiian fishing practice called Hukilau.

\section{Data Availability:}

The full list of publications on which this review is based are listed in Appendix 2. Data generated from those publications, that support the findings of this study, are available on request from the corresponding author.

\section{LITERATURE CITED}

Adjei, P. O.-W., D. Buor, and P. Addrah. 2017. Ecological health effects of rural livelihood and poverty reduction strategies in the Lake Bosomtwe basin of Ghana. GeoJournal 82(3):609-625. https://doi.org/10.1007/s10708-016-9707-1

Agrawal, A., and K. Redford. 2009. Conservation and displacement: an overview. Conservation and Society 7(1):1-10.

Agyare, A. K., G. Murray, P. Dearden, and R. Rollins. 2015. Understanding inter-community performance assessments in community-based resource management at Avu Lagoon, Ghana. Environment, Development and Sustainability 17(6):1493-1508. https://doi.org/10.1007/s10668-014-9617-7

Anaya, F. C., and M. Espírito-Santo. 2018. Protected areas and territorial exclusion of traditional communities: analyzing the social impacts of environmental compensation strategies in Brazil. Ecology and Society 23(1):8. https://doi.org/10.5751/ ES-09850-230108

Antwi, E. K., W. Owusu-Banahene, J. Boakye-Danquah, R. Mensah, J. D. Tetteh, M. Nagao, and K. Takeuchi. 2017. Sustainability assessment of mine-affected communities in Ghana: towards ecosystems and livelihood restoration. Sustainability Science 12(5):747-767. https://doi.org/10.1007/ s11625-017-0474-9

Apgar, J. M., J. M. Ataria, and W. J. Allen. 2011. Managing beyond designations: supporting endogenous processes for nurturing biocultural development. International Journal of Heritage Studies 17(6):555-570. https://doi.org/10.1080/13527258.2011.618250

Arambiza, E., and M. Painter. 2006. Biodiversity conservation and the quality of life of indigenous people in the Bolivian Chaco. Human Organization 65(1):20-34. https://doi.org/10.17730/ humo.65.1.86y $8 \mathrm{rem} 7 \mathrm{ugf} 8497 \mathrm{u}$

Armitage, D., C. Béné, A. T. Charles, D. Johnson, and E. H. Allison. 2012. The interplay of well-being and resilience in 
applying a social-ecological perspective. Ecology and Society 17 (4):15. http://dx.doi.org/10.5751/ES-04940-170415

Atela, J. O., P. A. Minang, C. H. Quinn, and L. A. Duguma. 2015. Implementing REDD+ at the local level: assessing the key enablers for credible mitigation and sustainable livelihood outcomes. Journal of Environmental Management 157:238-249. https://doi.org/10.1016/j.jenvman.2015.04.015

Ayala-Orozco, B., J. A. Rosell, J. Merçon, I. Bueno, G. AlatorreFrenk, A. Langle-Flores, and A. Lobato. 2018. Challenges and strategies in place-based multi-stakeholder collaboration for sustainability: learning from experiences in the Global South. Sustainability 10(9):3217. https://doi.org/10.3390/su10093217

Ban, N. C., G. G. Gurney, N. A. Marshall, C. K. Whitney, M. Mills, S. Gelcich, N. J. Bennett, M. C. Meehan, C. Butler, S. Ban, T. C. Tran, M. E. Cox, and S. J. Breslow. 2019. Well-being outcomes of marine protected areas. Nature Sustainability 2 (6):524-532. https://doi.org/10.1038/s41893-019-0306-2

Bawa, K. S., G. Joseph, and S. Setty. 2007. Poverty, biodiversity and institutions in forest-agriculture ecotones in the Western Ghats and Eastern Himalaya ranges of India. Agriculture, Ecosystems \& Environment 121(3):287-295. https://doi. org/10.1016/j.agee.2006.12.023

Bennett, N. J., R. Roth, S. C. Klain, K. Chan, P. Christie, D. A. Clark, G. Cullman, D. Curran, T. J. Durbin, G. Epstein, A. Greenberg, M. P. Nelson, J. Sandlos, R. Stedman, T. L. Teel, R. Thomas, D. Veríssimo, and C. Wyborn. 2017. Conservation social science: understanding and integrating human dimensions to improve conservation. Biological Conservation 205:93-108. https://doi.org/10.1016/j.biocon.2016.10.006

Berkes, F. 2009. Evolution of co-management: role of knowledge generation, bridging organizations and social learning. Journal of Environmental Management 90(5):1692-1702. https://doi. org/10.1016/j.jenvman.2008.12.001

Bhola, N., H. Klimmek, N. Kingston, N. D. Burgess, A. van Soesbergen, C. Corrigan, J. Harrison, and M. T. J. Kok. 2021. Perspectives on area-based conservation and its meaning for future biodiversity policy. Conservation Biology 35(1):168-178. https://doi.org/10.1111/cobi.13509

Biedenweg, K., and N. Gross-Camp. 2018. A brave new world: integrating well-being and conservation. Ecology and Society 23 (2):32. https://doi.org/10.5751/ES-09977-230232

Blackman, A., L. Corral, E. S. Lima, and G. P. Asner. 2017. Titling indigenous communities protects forests in the Peruvian Amazon. Proceedings of the National Academy of Sciences of the United States of America 114(16):4123-4128. https://doi.org/10.1073/ pnas. 1603290114

Borrini-Feyerabend, G., N. Dudley, T. Jaeger, B. Lassen, N. Pathak Broome, A. Phillips, and T. Sandwith. 2013. Governance of protected areas: from understanding to action. Best Practice Protected Area Guidelines Series No. 20. International Union for Conservation of Nature, Gland, Switzerland.

Borrini-Feyerabend, G., and R. Hill. 2015. Governance for the conservation of nature. Pages 169-206 in G. L. Worboys, M. Lockwood, A. Kothari, S. Feary, and I. Pulsford, editors.
Protected area governance and management. ANU Press, Canberra, Australia. https://doi.org/10.22459/pagm.04.2015

Borrini-Feyerabend, G., A. Kothari, and G. Oviedo. 2004. Indigenous and local communities and protected areas: towards equity and enhanced conservation. International Union for Conservation of Nature, Gland, Switzerland.

Brattland, C. 2013. Proving fishers right. Effects of the integration of experience-based knowledge in ecosystem-based management. Acta Borealia 30(1):39-59. https://doi.org/10.1080/08003831.2013.768053

Breslow, S. J., B. Sojka, R. Barnea, X. Basurto, C. Carothers, S. Charnley, S. Coulthard, N. Dolšak, J. Donatuto, C. GarcíaQuijano, C. C. Hicks, A. Levine, M. B. Mascia, K. Norman, M. Poe, T. Satterfield, K. St. Martin, and P. S. Levin. 2016. Conceptualizing and operationalizing human wellbeing for ecosystem assessment and management. Environmental Science \& Policy 66:250-259. https://doi.org/10.1016/j.envsci.2016.06.023

Bridgewater, P., M. Régnier, and R. C. García. 2015. Implementing SDG 15: Can large-scale public programs help deliver biodiversity conservation, restoration and management, while assisting human development? Natural Resources Forum 39:214-223. https://doi.org/10.1111/1477-8947.12084

Brosius, J. P. 2004. Indigenous peoples and protected areas at the World Parks Congress. Conservation Biology 18(3):609-612. https://doi.org/10.1111/j.1523-1739.2004.01834.X

Bunch, M. J. 2016. Ecosystem approaches to health and wellbeing: navigating complexity, promoting health in socialecological systems. Systems Research and Behavioral Science 33 (5):614-632. https://doi.org/10.1002/sres.2429

Büscher, B., and R. Fletcher. 2019. Towards convivial conservation. Conservation and Society 17(3):283-296.

Campos-Silva, J. V., J. E. Hawes, P. C. M. Andrade, and C. A. Peres. 2018. Unintended multispecies co-benefits of an Amazonian community-based conservation programme. Nature Sustainability 1(11):650-656. https://doi.org/10.1038/s41893-018-0170-5

Cao, S., X. Zheng, L. Chen, H. Ma, and J. Xia. 2017. Using the green purchase method to help farmers escape the poverty trap in semiarid China. Agronomy for Sustainable Development 37 (2):7. https://doi.org/10.1007/s13593-017-0420-3

Cash, D. W., W. Adger, F. Berkes, P. Garden, L. Lebel, P. Olsson, L. Pritchard, and O. Young. 2006. Scale and cross-scale dynamics: governance and information in a multilevel world. Ecology and Society 11(2):8. https://doi.org/10.5751/ES-01759-110208

Celentano, D., G. X. Rousseau, V. L. Engel, C. L. Façanha, E. M. de Oliveira, and E. G. de Moura. 2014. Perceptions of environmental change and use of traditional knowledge to plan riparian forest restoration with relocated communities in Alcântara, Eastern Amazon. Journal of Ethnobiology and Ethnomedicine 10:11. https://doi.org/10.1186/1746-4269-10-11

Chapin, III, F. S., S. R. Carpenter, G. P. Kofinas, C. Folke, N. Abel, W. C. Clark, P. Olsson, D. M. S. Smith, B. Walker, O. R. Young, F. Berkes, R. Biggs, J. M. Grove, R. L. Naylor, E. Pinkerton, W. Steffen, and F. J. Swanson. 2010. Ecosystem 
stewardship: sustainability strategies for a rapidly changing planet. Trends in Ecology \& Evolution 25(4):241-249. https://doi. org/10.1016/j.tree.2009.10.008

Cheng, S. H., C. Augustin, A. Bethel, D. Gill, S. Anzaroot, J. Brun, B. DeWilde, R. C. Minnich, R. Garside, Y. J. Masuda, D. C. Miller, D. Wilkie, S. Wongbusarakum, and M. C. McKinnon. 2018. Using machine learning to advance synthesis and use of conservation and environmental evidence. Conservation Biology 32(4):762-764. https://doi.org/10.1111/cobi.13117

Chhotray, V. 2016. Justice at sea: fishers' politics and marine conservation in coastal Odisha, India. Maritime Studies 15:8. https://doi.org/10.1186/s40152-016-0048-y

Chiaravalloti, R. 2019. The displacement of insufficiently 'traditional' communities: local fisheries in the Pantanal. Conservation and Society 17(2):173-183.

Christoplos, I., S. Anderson, M. Arnold, V. Galaz, M. Hedger, R. J. Klein, and K. L. Goulven. 2009. The human dimension of climate adaptation: the importance of local and institutional issues. Commission on Climate Change and Development, Stockholm, Sweden.

Convention on Biological Diversity (CBD). 2018. Conference of the Parties to the Convention on Biological Diversity Fourteenth meeting, Sharm El-Sheikh, Egypt, Decision 14/8, Protected areas and other effective area-based conservation measures, Annex II: Voluntary guidance on effective governance models for management of protected areas, including equity, taking into account work being undertaken under article 8(j) and related provisions.

Convention on Biological Diversity (CBD). 2021. First draft of the post-2020 global biodiversity framework. [online] URL: https://www.cbd.int/doc/c/abb5/591f/2e46096d3f0330b08ce87a45/ wg2020-03-03-en.pdf

Cook, C. N., R. S. Valkan, and M. A. McGeoch. 2019. Beyond total area protected: a new set of metrics to measure progress in building a robust protected area estate. Global Environmental Change 58:101963. https://doi.org/10.1016/j.gloenvcha.2019.101963

Cooper, N. A., and K. A. Kainer. 2018. To log or not to log: local perceptions of timber management and its implications for wellbeing within a sustainable-use protected area. Ecology and Society 23(2):4. https://doi.org/10.5751/ES-09995-230204

Coulthard, S., D. Johnson, and J. A. McGregor. 2011. Poverty, sustainability and human wellbeing: a social wellbeing approach to the global fisheries crisis. Global Environmental Change 21 (2):453-463. https://doi.org/10.1016/j.gloenvcha.2011.01.003

Cumming, G. S., G. Epstein, J. M. Anderies, C. I. Apetrei, J. Baggio, Ö. Bodin, S. Chawla, H. S. Clements, M. Cox, L. Egli, G. G. Gurney, M. Lubell, N. Magliocca, T. H. Morrison, B. Müller, R. Seppelt, M. Schlüter, H. Unnikrishnan, S. Villamayor-Tomas, and C. M. Weible. 2020. Advancing understanding of natural resource governance: a post-Ostrom research agenda. Current Opinion in Environmental Sustainability 44:26-34. https://doi. org/10.1016/j.cosust.2020.02.005

Curtin, C. G. 2014. Resilience design: toward a synthesis of cognition, learning, and collaboration for adaptive problem solving in conservation and natural resource stewardship. Ecology and Society 19(2):15. https://doi.org/10.5751/ES-06247-190215

Dahlberg, A. C., and C. Burlando. 2009. Addressing trade-offs: experiences from conservation and development initiatives in the Mkuze Wetlands, South Africa. Ecology and Society 14(2):37. https://doi.org/10.5751/ES-03183-140237

Dawson, N., A. Martin, and F. Danielsen. 2018. Assessing equity in protected area governance: approaches to promote just and effective conservation. Conservation Letters 11(2):e12388. https://doi.org/10.1111/conl.12388

de Souza, S. E. X. F. de, E. Vidal, G. de F. Chagas, A. T. Elgar, and P. H. S. Brancalion. 2016. Ecological outcomes and livelihood benefits of community-managed agroforests and second growth forests in Southeast Brazil. Biotropica 48(6):868-881. https://doi. org/10.1111/btp. 12388

Dearden, P., D. Emphandhu, S. Songpornwanich, and A. Ruksapol. 2017. Koh Pitak: a community-based, environment and tourism initiative in Thailand. Chapter 10 in D. Armitage, A. Charles, F. Berkes, editors. Governing the coastal commons: communities, resilience and transformation. Routledge, London, UK. https://doi.org/10.4324/9781315688480-10

Delabre, I., E. Boyd, M. Brockhaus, W. Carton, T. Krause, P. Newell, G. Y. Wong, and F. Zelli. 2020. Unearthing the myths of global sustainable forest governance. Global Sustainability 3:e16. https://doi.org/10.1017/sus.2020.11

Dhiaulhaq, A., T. De Bruyn, and D. Gritten. 2015. The use and effectiveness of mediation in forest and land conflict transformation in Southeast Asia: case studies from Cambodia, Indonesia and Thailand. Environmental Science \& Policy 45:132-145. https://doi.org/10.1016/i.envsci.2014.10.009

Diaz, S., J. Settele, E. S. Brondizio, H. T. Ngo, M. Gueze, J. Agard, A. Arneth, P. Balvanera, K. A. Brauman, S. H. M. Butchart, K. M. A. Chan, L. A. Garidbaldi, K. Ichii, J. Liu, S. M. Subramanian, G. F. Midgley, P. Miloslavich, Z. Molnar, D. Obura, A. Pffaf, S. Polasky, A. Purvis, J. Razzaque, B. Reyers, R. Roy Chowdhury, Y. J. Shin, I. J. Visseren-Hamakers, K. J. Willis, and C. N. Zayas. 2019. IPBES: Summary for policymakers of the global assessment report on biodiversity and ecosystem services of the Intergovernmental Science-Policy Platform on Biodiversity and Ecosystem Services. IPBES Secretariat, Bonn, Germany.

Díaz-Reviriego, I., E. Turnhout, and S. Beck. 2019. Participation and inclusiveness in the Intergovernmental Science-Policy Platform on Biodiversity and Ecosystem Services. Nature Sustainability 2(6):457-464. https://doi.org/10.1038/s41893-019-0290-6

Diemont, S. A. W., and J. F. Martin. 2009. Lacandon Maya ecosystem management: sustainable design for subsistence and environmental restoration. Ecological Applications 19(1):254-266. https://doi.org/10.1890/08-0176.1

Dressler, W., J. de Koning, M. Montefrio, and J. Firn. 2016. Land sharing not sparing in the "green economy": the role of livelihood bricolage in conservation and development in the Philippines. Geoforum 76:75-89. https://doi.org/10.1016/j.geoforum.2016.09.003

Dudley, N., H. Jonas, F. Nelson, J. Parrish, A. Pyhälä, S. Stolton, and J. E. M. Watson. 2018. The essential role of other effective 
area-based conservation measures in achieving big bold conservation targets. Global Ecology and Conservation 15: e00424. https://doi.org/10.1016/j.gecco.2018.e00424

Ferraro, P. J., and M. M. Hanauer. 2011. Protecting ecosystems and alleviating poverty with parks and reserves: 'win-win' or tradeoffs? Environmental and Resource Economics 48 (2):269-286. https://doi.org/10.1007/s10640-010-9408-Z

Ferraro, P. J., and M. M. Hanauer. 2015. Through what mechanisms do protected areas affect environmental and social outcomes? Philosophical Transactions of the Royal Society B: Biological Sciences 370(1681):20140267. https://doi.org/10.1098/ $\underline{\text { rstb. 2014.0267 }}$

Folke, C. 2004. Traditional knowledge in social-ecological systems. Ecology and Society 9(3):7. https://doi.org/10.5751/ ES-01237-090307

Folke, C., T. Hahn, P. Olsson, and J. Norberg. 2005. Adaptive governance of social-ecological systems. Annual Review of Environmental Resources 30:441-473. https://doi.org/10.1146/ annurev.energy.30.050504.144511

Franco, J. C., and S. M. Borras. 2019. Grey areas in green grabbing: subtle and indirect interconnections between climate change politics and land grabs and their implications for research. Land Use Policy 84:192-199. https://doi.org/10.1016/j. landusepol.2019.03.013

Freudenthal, E., M. F. Ferrari, J. Kenrick, and A. Mylne. 2012. The Whakatane mechanism: promoting justice in protected areas. Nomadic Peoples 16(2):84-94. https://doi.org/10.3167/np.2012.160207

Gannon, P., G. Dubois, N. Dudley, J. Ervin, S. Ferrier, S. Gidda, K. MacKinnon, K. Richardson, M. Schmidt, E. Seyoum-Edjigu, and A. Shestakov. 2019. Editorial essay: an update on progress towards Aichi Biodiversity Target 11. Parks 25(2):7-18. https:// doi.org/10.2305/IUCN.CH.2019.PARKS-25-2PG.en

Garnett, S. T., N. D. Burgess, J. E. Fa, Á. Fernández-Llamazares, Z. Molnár, C. J. Robinson, J. E. M. Watson, K. K. Zander, B. Austin, E. S. Brondizio, N. F. Collier, T. Duncan, E. Ellis, H. Geyle, M. V. Jackson, H. Jonas, P. Malmer, B. McGowan, A. Sivongxay, and I. Leiper. 2018. A spatial overview of the global importance of Indigenous lands for conservation. Nature Sustainability 1(7):369-374. https://doi.org/10.1038/s41893-018-0100-6

Gill, D. A., S. H. Cheng, L. Glew, E. Aigner, N. J. Bennett, and M. B. Mascia. 2019. Social synergies, tradeoffs, and equity in marine conservation impacts. Annual Review of Environment and Resources 44(1):347-372. https://doi.org/10.1146/annurevenviron-110718-032344

Gough, I., and J. A. McGregor. 2007. Wellbeing in developing countries: from theory to research. Cambridge University Press, Cambridge, UK. https://doi.org/10.1017/CBO9780511488986

Guerrero, A. M., N. J. Bennett, K. A. Wilson, N. Carter, D. Gill, M. Mills, C. D. Ives, M. J. Selinske, C. Larrosa, S. Bekessy, F. A. Januchowski-Hartley, H. Travers, C. A. Wyborn, and A. Nuno. 2018. Achieving the promise of integration in social-ecological research: a review and prospectus. Ecology and Society 23(3):38. https://doi.org/10.5751/es-10232-230338
Hall, J. M., N. D. Burgess, S. Rantala, H. Vihemäki, G. Jambiya, R. E. Gereau, F. Makonda, F. Njilima, P. Sumbi, and A. Kizaji. 2014. Ecological and social outcomes of a new protected area in Tanzania. Conservation Biology 28(6):1512-1521. https://doi. org/10.1111/cobi.12335

Hirsch, P. D., W. M. Adams, J. P. Brosius, A. Zia, N. Bariola, and J. L. Dammert. 2011. Acknowledging conservation trade-offs and embracing complexity. Conservation Biology 25(2):259-264. https://doi.org/10.1111/j.1523-1739.2010.01608.x

Hockings, M., J. Hardcastle, S. Woodley, T. Sandwith, J. Wilson, M. Bammert, S. Valenzuela, B. Chataigner, T. Lefebvre, F. Leverington, N. Lopoukhine, K. MacKinnon, and J. Miranda Londono. 2019. The IUCN Green list of protected and conserved areas: setting the standard for effective area-based conservation. Parks 25(2):57-66. https://doi.org/10.2305/IUCN.CH.2019. PARKS-25-2MH.en

Holmes, G. 2014. Defining the forest, defending the forest: political ecology, territoriality, and resistance to a protected area in the Dominican Republic. Geoforum 53:1-10. https://doi. org/10.1016/j.geoforum.2014.01.015

Hossain, M. S., F. Eigenbrod, F. A. Johnson, and J. A. Dearing. 2017. Unravelling the interrelationships between ecosystem services and human wellbeing in the Bangladesh delta. International Journal of Sustainable Development \& World Ecology 24(2):120-134. https://doi.org/10.1080/13504509.2016.1182087

Howe, C., H. Suich, B. Vira, and G. M. Mace. 2014. Creating winwins from trade-offs? Ecosystem services for human well-being: a meta-analysis of ecosystem service trade-offs and synergies in the real world. Global Environmental Change 28:263-275. https:// doi.org/10.1016/j.gloenvcha.2014.07.005

Huntsinger, L., and L. Diekmann. 2010. The virtual reservation: land distribution, natural resource access, and equity on the Yurok Forest. Natural Resources Journal 50:341.

Jonas, H., V. Barbuto, H. Jonas, A. Kothari, and F. Nelson. 2014. New steps of change: looking beyond protected areas to consider other effective area-based conservation measures. Parks 20:2. https://doi.org/10.2305/IUCN.CH.2014.PARKS-20-2.HDJ.en

Jones, K. W., C. L. Muñoz Brenes, X. A. Shinbrot, W. LópezBáez, and A. Rivera-Castañeda. 2018. The influence of cash and technical assistance on household-level outcomes in payments for hydrological services programs in Chiapas, Mexico. Ecosystem Services 31:208-218. https://doi.org/10.1016/j.ecoser.2018.04.008

Kideghesho, J. R. 2008. Co-existence between the traditional societies and wildlife in western Serengeti, Tanzania: its relevancy in contemporary wildlife conservation efforts. Biodiversity and Conservation 17(8):1861-1881. https://doi.org/10.1007/s10531-007-9306$\underline{Z}$

Larsen, P. B., P. Le Billon, M. Menton, J. Aylwin, J. Balsiger, D. Boyd, M. Forst, F. Lambrick, C. Santos, H. Storey, and S. Wilding. 2021. Understanding and responding to the environmental human rights defenders crisis: the case for conservation action. Conservation Letters 14:e12777. https://doi. org/10.1111/conl.12777 
Larson, A. M. 2003. Decentralisation and forest management in Latin America: towards a working model. Public Administration and Development 23(3):211-226. https://doi.org/10.1002/pad.271

Leach, M., I. Scoones, and A. Stirling. 2010. Governing epidemics in an age of complexity: narratives, politics and pathways to sustainability. Global Environmental Change 20(3):369-377. https://doi.org/10.1016/j.gloenvcha.2009.11.008

Lebel, L., J. M. Anderies, B. Campbell, C. Folke, S. HatfieldDodds, T. P. Hughes, and J. Wilson. 2006. Governance and the capacity to manage resilience in regional social-ecological systems. Ecology and Society 11(1):19. https://doi.org/10.5751/ ES-01606-110119

Lecuyer, L., R. M. White, B. Schmook, V. Lemay, and S. Calmé. 2018. The construction of feelings of justice in environmental management: an empirical study of multiple biodiversity conflicts in Calakmul, Mexico. Journal of Environmental Management 213:363-373. https://doi.org/10.1016/j.jenvman.2018.02.050

Lemos, M. C., and A. Agrawal. 2006. Environmental governance. Annual Review of Environment and Resources 31(1):297-325. https://doi.org/10.1146/annurev.energy.31.042605.135621

Lindsey, P., J. Allan, P. Brehony, A. Dickman, A. Robson, C. Begg, H. Bhammar, L. Blanken, T. Breuer, K. Fitzgerald, M. Flyman, P. Gandiwa, N. Giva, D. Kaelo, S. Nampindo, N. Nyambe, K. Steiner, A. Parker, D. Roe, P. Thomson, M. Trimble, A. Caron, and P. Tyrrell. 2020. Conserving Africa's wildlife and wildlands through the COVID-19 crisis and beyond. Nature Ecology \& Evolution 4(10):1300-1310. https://doi.org/10.1038/s41559-020-1275-6

Lindsey, P. A., V. R. Nyirenda, J. I. Barnes, M. S. Becker, R. McRobb, C. J. Tambling, W. A. Taylor, F. G. Watson, and M. t'Sas-Rolfes. 2014. Underperformance of African protected area networks and the case for new conservation models: insights from Zambia. PLOS ONE 9(5):e94109. https://doi.org/10.1371/ journal.pone.0094109

Liu, J., V. Hull, H. C. J. Godfray, D. Tilman, P. Gleick, H. Hoff, C. Pahl-Wostl, Z. Xu, M. G. Chung, J. Sun, and S. Li. 2018. Nexus approaches to global sustainable development. Nature Sustainability 1(9):466-476. https://doi.org/10.1038/s41893-018-0135-8

Lliso, B., U. Pascual, S. Engel, and P. Mariel. 2020. Payments for ecosystem services or collective stewardship of Mother Earth? Applying deliberative valuation in an indigenous community in Colombia. Ecological Economics 169:106499. https://doi. org/10.1016/j.ecolecon.2019.106499

Lockwood, M. 2010. Good governance for terrestrial protected areas: a framework, principles and performance outcomes. Journal of Environmental Management 91(3):754-766. https:// doi.org/10.1016/j.jenvman.2009.10.005

Loveridge, R., S. M. Sallu, I. J. Pesha, and A. R Marshall. 2020. Measuring human wellbeing: a protocol for selecting local indicators. Environmental Science \& Policy 114:461-469. https:// doi.org/10.1016/j.envsci.2020.09.002

Madden, F., and B. McQuinn. 2014. Conservation's blind spot: the case for conflict transformation in wildlife conservation. Biological Conservation 178:97-106. https://doi.org/10.1016/j. biocon.2014.07.015
Massé, F., and J. D. Margulies. 2020. The geopolitical ecology of conservation: the emergence of illegal wildlife trade as national security interest and the re-shaping of US foreign conservation assistance. World Development 132:104958. https://doi. org/10.1016/j.worlddev.2020.104958

Mbaiwa, J. 2011. The effects of tourism development on the sustainable utilisation of natural resources in the Okavango Delta, Botswana. Current Issues in Tourism 14(3):251-273. https://doi.org/10.1080/13683500.2011.555525

Mbaria, J., and M. Ogada. 2016. The big conservation lie: the untold story of wildlife conservation in Kenya. Lens \& Pens, Auburn, Washington, USA.

McKinnon, M. C., S. H. Cheng, S. Dupre, J. Edmond, R. Garside, L. Glew, M. B. Holland, E. Levine, Y. J. Masuda, D. C. Miller, et al. 2016. What are the effects of nature conservation on human well-being? A systematic map of empirical evidence from developing countries. Environmental Evidence 5:8. https://doi. org/10.1186/s13750-016-0058-7

Mcleod, E., M. Bruton-Adams, J. Förster, C. Franco, G. Gaines, B. Gorong, R. James, G. Posing-Kulwaum, M. Tara, and E. Terk. 2019. Lessons from the Pacific Islands: adapting to climate change by supporting social and ecological resilience. Frontiers in Marine Science 6. https://doi.org/10.3389/fmars.2019.00289

Mwakaje, A. G., E. Manyasa, N. Wawire, M. Muchai, D. Ongare, C. Mugoya, C. W. Masiga, and A. Nikundiwe. 2013. Communitybased conservation, income governance, and poverty alleviation in Tanzania: the case of Serengeti Ecosystem. Journal of Environment \& Development 22(1):51-73. https://doi. org/10.1177/1070496512471949

Nagendra, H., and E. Ostrom. 2012. Polycentric governance of multifunctional forested landscapes. International Journal of the Commons 6(2):104-133. https://doi.org/10.18352/ijc.321

Nayak, P. K., L. E. Oliveira, and F. Berkes. 2014. Resource degradation, marginalization, and poverty in small-scale fisheries: threats to social-ecological resilience in India and Brazil. Ecology and Society 19(2):73. https://doi.org/10.5751/ES-06656-190273

Newell, P., P. Pattberg, and H. Schroeder. 2012. Multiactor governance and the environment. Annual Review of Environment and Resources 37(1):365-387. https://doi.org/10.1146/annurevenviron-020911-094659

Nyirenda, V. R., B. A. Nkhata, O. Tembo, and S. Siamundele. 2018. Elephant crop damage: subsistence farmers' social vulnerability, livelihood sustainability and elephant conservation. Sustainability 10(10):3572. https://doi.org/10.3390/su10103572

Oldekop, J. A., G. Holmes, W. E. Harris, and K. L. Evans. 2016. A global assessment of the social and conservation outcomes of protected areas. Conservation Biology 30(1):133-141. https://doi. org/10.1111/cobi.12568

Ostrom, E., J. Burger, C. B. Field, R. B. Norgaard, and D. Policansky. 1999. Revisiting the commons: local lessons, global challenges. Science 284(5412):278-282. https://doi.org/10.1126/ science. 284.5412 .278

Otero, I., K. N. Farrell, S. Pueyo, G. Kallis, L. Kehoe, H. Haberl, C. Plutzar, P. Hobson, J. García-Márquez, B. Rodríguez-Labajos, 
et al. 2020. Biodiversity policy beyond economic growth. Conservation Letters 13:e12713. https://doi.org/10.1111/conl.12713

Palmer, C., G. Souza, E. Laray, V. Viana, and A. Hall. 2020. Participatory policies and intrinsic motivation to conserve forest commons. Nature Sustainability 3:620-627. https://doi. org/10.1038/s41893-020-0531-8

Pereira, L. M., T. Karpouzoglou, N. Frantzeskaki, and P. Olsson. 2018. Designing transformative spaces for sustainability in socialecological systems. Ecology and Society 23(4):32. https://doi. org/10.5751/ES-10607-230432

Persha, L., A. Agrawal, and A. Chhatre. 2011. Social and ecological synergy: local rulemaking, forest livelihoods, and biodiversity conservation. Science 331(6024):1606-1608. https:// doi.org/10.1126/science.1199343

Popay, J., H. Roberts, A. Sowden, M. Petticrew, L. Arai, M. Rodgers, N. Britten, K. Roen, and S. Duffy. 2006. Guidance on the conduct of narrative synthesis in systematic reviews. A product from the ESRC Methods Programme. Version 1. Lancaster University, Lancaster, UK.

Posey, D. A. 1999. Cultural and spiritual values of biodiversity. Intermediate Technology Publications, Nairobi, Kenya.

Rawat, V., Y.S. Rawat, and S. Shah. 2010. Indigenous knowledge and sustainable development in the Tones Valley of Garhwal Himalaya. Journal of Medicinal Plants Research 4:2043-2047. https://doi.org/10.5897/JMPR10.191

Reyes-García, V., Á. Fernández-Llamazares, P. McElwee, Z. Molnár, K. Öllerer, S. J. Wilson, and E. S. Brondizio. 2019. The contributions of Indigenous peoples and local communities to ecological restoration. Restoration Ecology 27(1):3-8. https://doi. org/10.1111/rec.12894

Rodriguez, I. 2017. Linking well-being with cultural revitalization for greater cognitive justice in conservation: lessons from Venezuela in Canaima National Park. Ecology and Society 22 (4):24. https://doi.org/10.5751/ES-09758-220424

Roe, D., G. Oviedo, L. Pabon, M. Painter, K. Redford, L. Siegele, J. Springer, D. Thomas, and K. W. Painemilla. 2010. Conservation and human rights: the need for international standards. Policy Briefing. International Institute for Environment and Development, London, UK.

Sabin, S., B. Dieudonne, J. Mitchell, J. White, C. Chin, and R. Morikawa. 2019. Community-based watershed change: a case study in eastern Congo. Forests 10(6):475. https://doi. org/10.3390/f10060475

Salomon, A. K., K. Lertzman, K. Brown, K. B. Wilson, D. Secord, and I. McKechnie. 2018. Democratizing conservation science and practice. Ecology and Society 23(1):44. https://doi. org/10.5751/ES-09980-230144

Saxby, H., M. Gkartzios, and K. Scott. 2018. 'Farming on the edge': wellbeing and participation in agri-environmental schemes. Sociologia Ruralis 58(2):392-411. https://doi.org/10.1111/ $\underline{\text { soru. } 12180}$

Scheidel, A., D. Del Bene, J. Liu, G. Navas, S. Mingorría, F. Demaria, S. Avila, B. Roy, I. Ertör, L. Temper, and J. Martínez-
Alier. 2020. Environmental conflicts and defenders: a global overview. Global Environmental Change 63:102104. https://doi. org/10.1016/j.gloenvcha.2020.102104

Schlager, E., and E. Ostrom. 1992. Property-rights regimes and natural resources: a conceptual analysis. Land Economics 68 (3):249-262. https://doi.org/10.2307/3146375

Schleicher, J., J. Eklund, M. D. Barnes, J. Geldmann, J. A. Oldekop, and J. P. G. Jones. 2020. Statistical matching for conservation science. Conservation Biology 34(3):538-549. https://doi.org/10.1111/cobi.13448

Schleicher, J., C. A. Peres, T. Amano, W. Llactayo, and N. LeaderWilliams. 2017. Conservation performance of different conservation governance regimes in the Peruvian Amazon. Scientific Reports 7:11318. https://doi.org/10.1038/s41598-017-10736$\underline{\mathrm{W}}$

Schnegg, M., and R. D. Kiaka. 2018. Subsidized elephants: community-based resource governance and environmental (in) justice in Namibia. Geoforum 93:105-115. https://doi. org/10.1016/j.geoforum.2018.05.010

Schreckenberg, K., P. Franks, A. Martin, and B. Lang. 2016. Unpacking equity for protected area conservation. PARKS 22:11-28. https://doi.org/10.2305/IUCN.CH.2016.PARKS-22-2KS. en

Sikor, T., A. Martin, J. Fisher, and J. He. 2014. Toward an empirical analysis of justice in ecosystem governance. Conservation Letters 7(6):524-532. https://doi.org/10.1111/ conl.12142

Skutsch, M., and E. Turnhout. 2020. REDD+: If communities are the solution, what is the problem? World Development 130:104942. https://doi.org/10.1016/j.worlddev.2020.104942

Snilstveit, B., S. Oliver, and M. Vojtkova. 2012. Narrative approaches to systematic review and synthesis of evidence for international development policy and practice. Journal of Development Effectiveness 4(3):409-429. https://doi. org/10.1080/19439342.2012.710641

Sterling, E. J., C. Filardi, A. Toomey, A. Sigouin, E. Betley, N. Gazit, J. Newell, S. Albert, D. Alvira, N. Bergamini, M. Blair, D. Boseto, K. Burrows, N. Bynum, S. Caillon, J. E. Caselle, J. Claudet, G. Cullman, R. Dacks, P. B. Eyzaguirre, S. Gray, J. Herrera, P. Kenilorea, K. Kinney, N. Kurashima, S. Macey, C. Malone, S. Mauli, J. McCarter, H. McMillen, P. Pascua, P. Pikacha, A. L. Porzecanski, P. de Robert, M. Salpeteur, M. Sirikolo, M. H. Stege, K. Stege, T. Ticktin, R. Vave, A. Wali, P. West, K. B. Winter, and S. D. Jupiter. 2017. Biocultural approaches to well-being and sustainability indicators across scales. Nature Ecology \& Evolution 1(12):1798-1806. https://doi.org/10.1038/s41559-017-0349-6

Tai, H.-S. 2007. Development through conservation: an institutional analysis of Indigenous community-based conservation in Taiwan. World Development 35(7):1186-1203. https://doi. org/10.1016/j.worlddev.2006.09.015

Tauli-Corpuz, V., J. Alcorn, A. Molnar, C. Healy, and E. Barrow. 2020. Cornered by PAs: adopting rights-based approaches to enable cost-effective conservation and climate action. World Development 130:104923. https://doi.org/10.1016/j.worlddev.2020.104923 
Terer, T., A. M. Muasya, F. Dahdouh-Guebas, G. G. Ndiritu, and L. Triest. 2012. Integrating local ecological knowledge and management practices of an isolated semi-arid papyrus swamp

(Loboi, Kenya) into a wider conservation framework. Journal of Environmental Management 93(1):71-84. https://doi.org/10.1016/ j.jenvman.2011.08.005

Thondhlana, G., S. M. Redpath, P. O. Vedeld, L. van Eeden, U. Pascual, K. Sherren, and C. Murata. 2020. Non-material costs of wildlife conservation to local people and their implications for conservation interventions. Biological Conservation 246:108578. https://doi.org/10.1016/j.biocon.2020.108578

Thornton, T. F., R. K. Puri, S. Bhagwat, and P. Howard. 2019. Human adaptation to biodiversity change: an adaptation process approach applied to a case study from southern India. Ambio 48 (12):1431-1446. https://doi.org/10.1007/s13280-019-01225-7

Tran, T. C., N. C. Ban, and J. Bhattacharyya. 2020. A review of successes, challenges, and lessons from Indigenous protected and conserved areas. Biological Conservation 241:108271. https://doi. org/10.1016/j.biocon.2019.108271

Vaughan, A. 2020. World leaders pledge to protect nature - will it make a difference? New Scientist 248(3303): 18.

Vergara, E. P., and J. R. Barton. 2013. Poverty and dependency in Indigenous rural livelihoods: Mapuche experiences in the Andean foothills of Chile. Journal of Agrarian Change 13 (2):234-262. https://doi.org/10.1111/j.1471-0366.2012.00380.x

von der Porten, S., Y. Ota, A. Cisneros-Montemayor, and S. Pictou. 2019. The role of Indigenous resurgence in marine conservation. Coastal Management 47(6):527-547. https://doi. org/10.1080/08920753.2019.1669099

West, P., J. Igoe, and D. Brockington. 2006. Parks and peoples: the social impact of protected areas. Annual Review of Anthropology 35:251-277. https://doi.org/10.1146/annurev. anthro.35.081705.123308

Wilson, G. A. 2012. Community resilience, globalization, and transitional pathways of decision-making. Geoforum 43 (6):1218-1231. https://doi.org/10.1016/j.geoforum.2012.03.008

Witter, R., and T. Satterfield. 2019. The ebb and flow of Indigenous rights recognitions in conservation policy. Development and Change 50(4):1083-1108. https://doi. org/10.1111/dech.12456

Woodhouse, E., and J. T. McCabe. 2018. Well-being and conservation: diversity and change in visions of a good life among the Maasai of northern Tanzania. Ecology and Society 23(1):43. https://doi.org/10.5751/ES-09986-230143

Xu, J., L. Lebel, and J. Sturgeon. 2009. Functional links between biodiversity, livelihoods, and culture in a Hani swidden landscape in southwest China. Ecology and Society 14(2):20. https://doi. org/10.5751/ES-02916-140220

Zafra-Calvo, N., U. Pascual, D. Brockington, B. Coolsaet, J. A. Cortes-Vazquez, N. Gross-Camp, I. Palomo, and N. D. Burgess. 2017. Towards an indicator system to assess equitable management in protected areas. Biological Conservation 211:134-141. https://doi.org/10.1016/j.biocon.2017.05.014 


\section{Appendix 1. Search strings}

The search terms were developed by a working group of members of the International Union for the Conservation of Nature's Commission on Environmental, Economic and Social Policy, comprising over 20 academics and practitioners from, and working, across the world. The group suggested various terms they had encountered in published studies, added synonyms or component terms used in different disciplines, elaborated terms with multiple meanings and refined the search string until the group deemed it suitable to capture a sufficiently broad range of relevant literature.

Our search for studies published up to 30th Sept 2019, on Web of Science, returned 3100 publications.

Part 1: Wellbeing and related concepts

TS=("wellbeing” OR "well-being” OR "equity" OR "justice” OR "sustainable livelihood*” OR "poverty" OR "basic need*” OR "quality of life" OR "buen vivir" OR "human right*" OR "social impact*” OR "social outcome*" OR "human welfare")

Part 2: Conservation terms

AND TS=("conservation" OR "conservanc*" OR "protected area*" OR "conserved area*" OR "nature reserve*" OR "nature preservation" OR "indigenous territor*" OR "restoration" OR "wildlife protection" OR “wildlife management" OR “wildlife preservation" OR "ecosystem management" OR "ecosystem governance" OR "natural resource management" OR "natural resource governance")

Part 3: Qualifier to ensure focus on local communities, livelihoods, development and aspects of governance.

AND TS=("local communit*" OR "local people" OR "local scale*" OR "local stakeholder*" OR "local actor*” OR "indigenous people*" OR "traditional knowledge" OR "traditional ecological knowledge" OR "TEK" OR "ILK" OR "traditional practice*” OR "local knowledge" OR "human dimension*" OR "institution*" OR "subsistence" OR "coproduction" OR "co-production" OR "tenure" OR "recognition" OR "procedure*” OR "participation" OR "stakeholder engagement” OR “community engagement” OR "customary" OR "distributive justice" OR "costs and benefits" OR "distribution of costs" OR "distribution of benefits" OR "benefit sharing" OR "benefit-sharing" OR "access" OR "entitlement*” OR "territor*” OR "attitude*” OR "local support" OR "cooperat*” OR "conflict*” OR "collaborat*” OR "trust" OR "steward*” OR "guardian*” OR "defend*” OR "custodian*” OR "enforcement" OR "regulation*” OR "rule*” OR "incentiv*” OR "motivat*" OR "social feedback*” OR "perception*" OR "perceive*" OR "governance" OR "govern" OR "governing” OR "decision-making" OR "decision making" OR "legitima*” OR "comanage*” OR "co-manage*” OR "human behaviour*” OR "livelihood*” OR "conservation and development" OR "social development" OR "human development") 
Part 4: Qualifier to capture studies with a focus on conservation effectiveness.

AND TS=("biodiversity" OR "species diversity" OR "biodiverse" OR "biological diversity" OR "habitat" OR "habitats" OR "ecosystem" OR “*forestation" OR "conservation goal*” OR "conservation objective*" OR "conservation target*” OR "conservation impact" OR "degrad*" OR "extinction*" OR "management effectiveness" OR "effective management" OR "conservation effectiveness" OR "effective conservation" OR "area effectiveness" OR "sustainable use" OR "sustainable utilisation" OR "sustainable utilization" OR "sustainable resource" OR "conservation success" OR "successful conservation" OR "conservation outcome*” OR "enhance*” OR "ecological effectiveness" OR "ecological goal*” OR "ecological objective*" OR "ecological impact*” OR "ecological sustainability" OR "environmental impact*” OR "environmental outcome*” OR "environmental objective*”) 
Appendix 2. Publications included in the review.

Table A2.1. List of the 169 articles included in the review (Authors short form, article title, year published)

\begin{tabular}{lll}
\hline \hline Authors & Publication Title & $\begin{array}{l}\text { Publication } \\
\text { Year }\end{array}$ \\
\hline Adams et al. & $\begin{array}{l}\text { Diversifying Incomes and Losing Landscape Complexity in } \\
\text { Quilombola Shifting Cultivation Communities of the Atlantic } \\
\text { Rainforest (Brazil) }\end{array}$ & 2013 \\
& &
\end{tabular}

Adjei et al. Ecological health effects of rural livelihood and poverty reduction strategies in the Lake Bosomtwe basin of Ghana

Afroz et al. Ideals and institutions: Systemic reasons for the failure of a social forestry program in south-west Bangladesh

Agyare et al. Understanding inter-community performance assessments in community-based resource management at Avu Lagoon, Ghana

Ahmed et al. Biodiversity and phytochemical quality in indigenous and state-supported tea management systems of Yunnan, China

Almeyda et al. Ecotourism Impacts in the Nicoya Peninsula, Costa Rica 2010

Anaya et al. $\quad$ Protected areas and territorial exclusion of traditional 2018 communities: analyzing the social impacts of environmental compensation strategies in Brazil

Antwi et al. Sustainability assessment of mine-affected communities in Ghana: towards ecosystems and livelihood restoration

Apgar et al. Managing beyond designations: supporting endogenous processes for nurturing biocultural development

Arambiza et al. Biodiversity conservation and the quality of life of indigenous people in the Bolivian Chaco

Atela et al. Implementing REDD plus at the local level: Assessing the key enablers for credible mitigation and sustainable livelihood outcomes

Ayuttacorn Social networks and the resilient livelihood strategies of Daraang women in Chiang Mai, Thailand

Ball et al. Governance challenges for commercial exploitation of a nontimber forest product by marginalized rural communities 
Bawa et al.

Becker

Bidaud et al.

Bonet-Garcia et

al.

Bose et al.

Brattland

Bremer et al.

Bremer et al.

Brichieri-

Colombi et al.

Brooks et al.

Brown et al.

Brown et al.

Bunch

Cagalanan
Poverty, biodiversity and institutions in forest-agriculture ecotones in the Western Ghats and Eastern Himalaya ranges of India

Grassroots to grassroots: Why forest preservation was rapid at

2003 Loma Alta, Ecuador

The local costs of biodiversity offsets: Comparing standards, policy and practice

2018

Protected areas as elicitors of human well-being in a

2015

developed region: A new synthetic (socioeconomic) approach

Does environmental certification in coffee promote "business as usual"? A case study from the Western Ghats, India

2016

Proving Fishers Right. Effects of the Integration of Experience-Based Knowledge in Ecosystem-Based Management

Biocultural Restoration of Traditional Agriculture: Cultural,

2018

Environmental, and Economic Outcomes of Lo"i Kalo

Restoration in He"eia, O"ahu

Conservation and livelihood outcomes of payment for ecosystem services in the Ecuadorian Andes: What is the potential for 'win-win'?

Standardizing the evaluation of community-based

$2018 / 2010$

conservation success; Ten years of adaptive communitygoverned conservation: evaluating biodiversity protection and poverty alleviation in a West African hippopotamus reserve

Sustained by Snakes? Seasonal Livelihood Strategies and Resource Conservation by Tonle Sap Fishers in Cambodia

Poverty Alleviation and Environmental Restoration Using the Clean Development Mechanism: A Case Study from Humbo, Ethiopia

Institutional choice and local legitimacy in community-based forest management: lessons from Cameroon

Ecosystem Approaches to Health and Well-Being: Navigating

2016

Complexity, Promoting Health in Social-Ecological Systems

Integrated Conservation and Development: Impacts on

Households in a Philippine Park 
Campos-Silva et Unintended multispecies co-benefits of an Amazonian

al.

Cao et al.

Cao et al.

Caro-Borrero et

al.

Carr

Castillo-

Eguskitza et al.

Celentano et al. Perceptions of environmental change and use of traditional

Chechina et al. Balancing Conservation and Livelihoods: A Study of Forest-

Chhotray

Chia et al.

Clements and

Milner-Gulland

Coomes and

Takasaki

Cooper and

Kainer

Cullen et al.

Dahlberg and

Burlando knowledge to plan riparian forest restoration with relocated communities in Alcantara, Eastern Amazon dependent Communities in the Philippines

Using the green purchase method to help farmers escape the poverty trap in semiarid China

A win-win strategy for ecological restoration and biodiversity conservation in Southern China

"We are the city lungs": Payments for ecosystem services in

2015 the outskirts of Mexico City

A tale of two roads: Land tenure, poverty, and politics on the Guatemalan frontier

Urdaibai Biosphere Reserve (Biscay, Spain): Conservation

Justice at Sea: Fishers' politics and marine conservation in coastal Odisha, India

Securing well-being with the advent of climate hazards Case of forest-dependent communities in a landscape in the Congo Basin

Impact of payments for environmental services and protected areas on local livelihoods and forest conservation in northern Cambodia

Targeting conservation-development initiatives in tropical forests: insights from analyses of rain forest use and economic reliance among Amazonian peasants

To log or not to log: local perceptions of timber management and its implications for well-being within a sustainable-use protected area

Land reform and biodiversity conservation in Brazil in the 1990s: Conflict and the articulation of mutual interests

Addressing Trade-offs: Experiences from Conservation and Development Initiatives in the Mkuze Wetlands, South Africa 
Daw et al. Elasticity in ecosystem services: exploring the variable relationship between ecosystems and human well-being

Dawson et al. Environmental justice research shows the importance of social 2017 feedbacks in ecosystem service trade-offs

Dawson and Assessing the contribution of ecosystem services to human

Martin wellbeing: A disaggregated study in western Rwanda

de Koning et al. Bridging the gap between forest conservation and poverty alleviation: the Ecuadorian Socio Bosque program

Derkzen et al. Shifts in ecosystem services in deprived urban areas: understanding people's responses and consequences for wellbeing

Desbureaux and Rain, forests and farmers: Evidence of drought induced

Damania deforestation in Madagascar and its consequences for biodiversity conservation

Dewi et al. Village economic opportunity, forest dependence, and rural livelihoods in East Kalimantan, Indonesia

Diemont and Lacandon Maya ecosystem management: sustainable design

Martin for subsistence and environmental restoration

Dressler et al. Land sharing not sparing in the "green economy": The role of livelihood bricolage in conservation and development in the Philippines

Endamana et al. A framework for assessing conservation and development in a Congo Basin Forest Landscape

Endamana et al. Unravelling the interrelationships between ecosystem services and human wellbeing in the Bangladesh delta

Fan et al.

Solving one problem by creating a bigger one: The consequences of ecological resettlement for grassland restoration and poverty alleviation in Northwestern China

Fauzi and

Buchary

Fedele et al.

Fisher et al.
A socioeconomic perspective of environmental degradation at Kepulauan Seribu Marine National Park, Indonesia

Reducing risks by transforming landscapes: Cross-scale effects of land-use changes on ecosystem services

Linking notions of justice and project outcomes in carbon offset forestry projects: Insights from a comparative study in Uganda 
Franco de Souza Ecological outcomes and livelihood benefits of community-

et al. managed agroforests and second growth forests in Southeast Brazil

Garcia-Fajardo et Land Management Strategies and their Implications for

Gardner et al. Protected areas for conservation and poverty alleviation: experiences from Madagascar

Garrett et al. Explaining the persistence of low income and environmentally 2017 degrading land uses in the Brazilian Amazon

Gill et al.

Moving beyond rhetoric: The need for participatory forest management with the Jakun of south-east Pahang, Malaysia

Giva and Raitio "Parks with People' in Mozambique: Community Dynamic

Responses to Human-Elephant Conflict at Limpopo National Park

Gjertsen

Can habitat protection lead to improvements in human wellbeing? Evidence from marine protected areas in the Philippines

Gockel and Gray Integrating Conservation and Development in the Peruvian Amazon

Gray

What kind of intensification? Agricultural practice, soil fertility and socioeconomic differentiation in rural Burkina Faso

Gross-Camp et al. Payments for ecosystem services in an African protected area: exploring issues of legitimacy, fairness, equity and effectiveness

Gustavsson et al. Procedural and distributive justice in a community-based managed Marine Protected Area in Zanzibar, Tanzania

Hagos and Tenure security, resource poverty, public programs, and

Holden household plot-level conservation investments in the highlands of northern Ethiopia

Hall et al. The relationship between forest cover and diet quality: a case study of rural southern Malawi 
Hall et al. Ecological and Social Outcomes of a New Protected Area in Tanzania

Haque et al. Integrating Conservation with Livelihood Improvement for

Sustainable Development: The Experiment of an Oyster

Producers' Cooperative in Southeast Brazil

Harbi et al. Making a bridge between livelihoods and forest conservation:

Lessons from non timber forest products' utilization in South

Sumatera, Indonesia

Harris et al. Integrating family planning service provision into community- 2012 based marine conservation

Hausser et al. Bees, farmers, tourists and hunters: conflict dynamics around Western Tanzania protected areas

Heagney et al. Socio-economic benefits from protected areas in southeastern Australia

Holmes

Defining the forest, defending the forest: Political ecology, territoriality, and resistance to a protected area in the Dominican Republic

Huang Lin and

Shao

Huang; Lin and

Shao

Huntsinger and

Diekmann

Islam et al.

Jadhav and Barua

Jones et al.

Jones et al.

Kangalawe and

Noe
Forest restoration to achieve both ecological and economic progress, Poyang Lake basin, China

Improving ecological conservation and restoration through payment for ecosystem services in Northeastern Tibetan Plateau, China

The Virtual Reservation: Land Distribution, Natural Resource Access, and Equity on the Yurok Forest

Social Considerations of Large River Sanctuaries: A Case Study from the Hilsa Shad Fishery in Bangladesh

2012 people's wellbeing

The influence of cash and technical assistance on householdlevel outcomes in payments for hydrological services programs in Chiapas, Mexico

Forest conservation incentives and deforestation in the Ecuadorian Amazon

Biodiversity conservation and poverty alleviation in 
Karanth

Khan and Khan

Kideghesho

Kitamura and

Clapp

Kumar et al.

Lamers et al.

Lammers et al.

Langston et al.

Lecuyer et al.

Lewis et al.

Liles et al.

Lindsey et al.

Locatelli et al.

Loring

Ma et al.
Making resettlement work: The case of India's Bhadra wildlife 2007 sanctuary

Assessing poverty-deforestation links: Evidence from Swat, 2009 Pakistan

Co-existence between the traditional societies and wildlife in

2008 western Serengeti, Tanzania: its relevancy in contemporary wildlife conservation efforts

Common property protected areas: Community control in 2013 forest conservation

Assessing wetland ecosystem services and poverty interlinkages: a general framework and case study Kenya

The challenges of community-based conservation in developing countries-A case study from Lake Alaotra, Madagascar

Estate Crops More Attractive than Community Forests in West Kalimantan, Indonesia management: An empirical study of multiple biodiversity conflicts in Calakmul, Mexico

Community Markets for Conservation (COMACO) links biodiversity conservation with sustainable improvements in livelihoods and food production

Connecting international priorities with human wellbeing in low-income regions: lessons from hawksbill turtle conservation in El Salvador

Underperformance of African Protected Area Networks and 2014 the Case for New Conservation Models: Insights from Zambia Impacts of payments for environmental services on local 2008 development in northern Costa Rica: A fuzzy multi-criteria analysis

Toward a Theory of Coexistence in Shared Social-Ecological Systems: The Case of Cook Inlet Salmon Fisheries

Conservation, ecotourism, poverty, and income inequality - A 2019 case study of nature reserves in Qinling, China 
MacKenzie

Madulu

Maikhuri et al.

Majambu et al.

Maliao and

Polohan

Manuel Torres-

Rojo et al.

Martin et al.

Martin et al.

Mbaiwa

McNally et al.

Montambault et al.

Moore et al.

Morais et al.

Morsello et al.

\section{MICROENTREPRENEURSHIP AMONG NAMIBIAN COMMUNITIES}

WILDLIFE CONSERVATION THROUGH TOURISM

The Effects of Processing Non-Timber Forest Products and 
Murphy et al. Place-making to transform urban social-ecological systems:

insights from the stewardship of urban lakes in Bangalore,

India

Murray and

Understanding Power in Indigenous Protected Areas: the Case

2017

Burrows of the Tla-o-qui-aht Tribal Parks

Mwakaje et al. Community-Based Conservation, Income Governance, and

Poverty Alleviation in Tanzania: The Case of Serengeti

Ecosystem

Nautiyal

Can conservation and development interventions in the Indian

Central Himalaya ensure environmental sustainability? A

socioecological evaluation

Nayak et al. Resource degradation, marginalization, and poverty in smallscale fisheries: threats to social- ecological resilience in India and Brazil

Neba

Population dynamics, rural livelihoods and forest protection projects in Sub-Saharan Africa: experiences from Santa, Cameroon

Ngome et al. Assessing household food insecurity experience in the context of deforestation in Cameroon

Nhem et al. The impact of forest resource decline: Analyzing forestrelated income supplements to reduce income inequality and poverty of the Kouy indigenous people living in Kampong Thom province, Cambodia

Nyirenda et al. Elephant Crop Damage: Subsistence Farmers' Social Vulnerability, Livelihood Sustainability and Elephant Conservation

Oelrichs et al. Strategies for mitigating forest arson and elephant conflict in Way Kambas National Park, Sumatra, Indonesia

Pacheco et al. Perspectives on Sustainable Resource Conservation in Community Nature Reserves: A Case Study from Senegal

Parraguez

Poverty and Dependency in Indigenous Rural Livelihoods:

Vergara and Mapuche Experiences in the Andean Foothills of Chile

Barton

Perez-Llorente et al. 
Price and

Leviston

Qiu

Quach and Ngoc

Rastogi et al.

Rawat et al.

Reddy et al.

Reyers et al.

Rico Garcia-

Amado et al.

Roy

Sabin et al.

Saxby et al.

Saxena et al.

Scales et al.

Schnegg and

Kiaka

Seghezzo et al.
Predicting pro-environmental agricultural practices: The social, psychological and contextual influences on land management

The Sanya Coral Reef National Marine Nature Reserve, China: A governance analysis

Impacts on the ecosystem and human well-being of the marine

2018 protected area in $\mathrm{Cu}$ Lao Cham, Vietnam

Wildlife-tourism, local communities and tiger conservation: A

2015 village-level study in Corbett Tiger Reserve, India

Indigenous knowledge and sustainable development in the Tones Valley of Garhwal Himalaya

Consequences of a Government-Controlled Agricultural Price

2014 Increase on Fishing and the Coral Reef Ecosystem in the Republic of Kiribati

Ecosystem Services, Land-Cover Change, and Stakeholders: Finding a Sustainable Foothold for a Semiarid Biodiversity Hotspot

Efficiency of Payments for Environmental Services: Equity and additionality in a case study from a Biosphere Reserve in Chiapas, Mexico

Local community attitudes towards mangrove forest conservation: Lessons from Bangladesh

Community-Based Watershed Change: A Case Study in Eastern Congo

Farming on the Edge': Wellbeing and Participation in AgriEnvironmental Schemes lessons from the Himalaya

Madagascar: lime production as an emerging threat

Subsidized elephants: Community-based resource governance and environmental (in)justice in Namibia

Native Forests and Agriculture in Salta (Argentina): 
Semwal et al. Patterns and ecological implications of agricultural land-use changes: a case study from central Himalaya, India

Sene-Harper et al. Leveraging local livelihood strategies to support conservation 2019 and development in West Africa

Sheng et al. Ecological and socioeconomic effects of ecological restoration in Chins's Three Rivers Source Region

Silva et al. Examining aspiration's imprint on the landscape: Lessons from Mozambique's Limpopo National Park

Steward

From colonization to "environmental soy": A case study of environmental and socio-economic valuation in the Amazon soy frontier

Suyanto et al. Poverty and environmental services: Case study in way Besai watershed, Lampung Province, Indonesia

Svarstad and Nothing succeeds like success narratives: a case of

Benjaminsen conservation and development in the time of REDD

Tai

Development through conservation: An institutional analysis of indigenous community-based conservation in Taiwan

Tekalign et al. Forest cover loss and recovery in an East African remnant forest area: Understanding its context and drivers for conservation and sustainable ecosystem service provision

Terer et al. Integrating local ecological knowledge and management practices of an isolated semi-arid papyrus swamp (Loboi, Kenya) into a wider conservation framework

Timah et al. Demographic pressure and natural resources conservation

Toillier and Farmers' adaptation capacities in the eastern rainforest of

Lardon Madagascar From forest-clearers to environmental managers

Torell et al.

Examining the linkages between AIDS and biodiversity conservation in coastal Tanzania

Tran

Combining biodiversity conservation with poverty alleviation

- a case study in the Mekong Delta, Vietnam

Twyman

Livelihood opportunity and diversity in Kalahari Wildlife Management Areas, Botswana: Rethinking community resource management

Unsworth et al. Food supply depends on seagrass meadows in the coral triangle 
Vandergeest

Property rights in protected areas: Obstacles to community

Vilardy et al. Relationships between hydrological regime and ecosystem services supply in a Caribbean coastal wetland: a socialecological approach

Violato Espada

Logging Community-Based Forests in the Amazon: An

and Sobrinho

Analysis of External Influences, Multi-Partner Governance, and Resilience

Vongvisouk et al. Rush for cash crops and forest protection: Neither land sparing nor land sharing

Wannasai and Role of land tenure security and farm household

Shrestha characteristics on land use change in the Prasae Watershed, Thailand

Witter and Rhino poaching and the "slow violence" of conservation-

Satterfield related resettlement in Mozambique's Limpopo National Park

$\mathrm{Xu}$ et al.

Functional Links Between Biodiversity, Livelihoods, and Culture in a Hani Swidden Landscape in Southwest China

Yirga and Hassan Poverty soil conservation efforts among smallholder farmers in the central highlands of Ethiopia

Zackey Peasant perspectives on deforestation in southwest China: 
Appendix 3. Selection of studies for review and data coding procedure.

\section{Screening process}

First, titles and abstracts were assessed for the 3100 publications identified by the literature search to determine whether they meeting the selection criteria. Two of the authors completed the screening process, utilising Colandr software to initially screen the same 100 publications to ensure consistent application of inclusion criteria, with all divergent decisions discussed and agreed upon. The inclusion rate averaged approximately $20 \%$ of the first 1000 publications screened, then dropped to less than $10 \%$ of the second 1000 publications with approximately five included per hundred at that stage. After 2200 publications had been screened at abstract level titles were scanned, through which a small number of relevant studies were identified and included. This resulted in 307 selected for full review.

During full review, a further 138 papers were excluded. Many did not adequately conceptualise both the well-being of IPLCs and conservation effectiveness to provide a complete picture of links between them. For example, some focused on the 'conservation attitude' of IPLCs, which was deemed insufficient as a proxy for conservation effectiveness. Others were excluded because they did not provide evidence for the claims made in the title or abstract. Our stringent inclusion requirements also helped to exclude studies exhibiting bias, for example by assuming that traditional ecological knowledge automatically leads to sustainable resource use or that lower material poverty in an area results in reduced environmental degradation, without providing supporting evidence. We also excluded 12 studies meeting the primary criteria, but involving multiple cases, for which the description of any single case was too limited to extract sufficient detail about the specific relationships and pathways. Among the nine publications that involved three or less cases and met our criteria, we included the case that was afforded most attention in the study or the case that best met the inclusion criteria.

\section{Data coding procedure}

Eleven individuals completed the data extraction between June and November 2019. All are scientists working on social dimensions of conservation or conservation governance, and ten of the eleven are listed among the authors. More than two thirds of publications were reviewed by one of three reviewers, including the lead author. In addition to the protocol, descriptive guidance was provided to all reviewers on inclusion/exclusion decisions, as well as type of and how much detail to provide, and on distinguishing findings supported by empirical evidence from unsubstantiated claims. The lead author and reviewers discussed papers and provided two-way feedback after initial reviews until both were comfortable with decision making and levels of consistency. All inclusion/exclusion decisions made at full review stage were verified by revisiting the original publication, and extracted data were checked by the lead author for completeness and accuracy. 
Table A3.1 Review protocol

\begin{tabular}{|c|c|c|c|}
\hline Topic & $\#$ & Variable & Notes/ Categories \\
\hline \multirow[t]{3}{*}{$\begin{array}{l}\text { Study } \\
\text { characteristics }\end{array}$} & 1 & $\begin{array}{l}\text { Number of cases included in } \\
\text { paper }\end{array}$ & $\begin{array}{l}\text { If more than one case, separate by } \\
\text { using extra lines }\end{array}$ \\
\hline & 2 & $\begin{array}{l}\text { Year/range of years of case } \\
\text { study/ data analysed (not year } \\
\text { of publication) }\end{array}$ & \\
\hline & 3 & $\begin{array}{l}\text { Study not suitable for review } \\
\text { - recommend exclusion. Mark } \\
\text { box with X. Do not continue. }\end{array}$ & $\begin{array}{l}\text { Each study must consider a) aspect o } \\
\text { Indigenous Peoples and Local } \\
\text { Communities' (IPLC's) well-being, } \\
\text { b) conservation (ecological) } \\
\text { effectiveness, c) empirical findings } \\
\text { linking IPLC well-being and } \\
\text { effectiveness (not assumed or } \\
\text { potential links). }\end{array}$ \\
\hline \multirow[t]{3}{*}{$\begin{array}{l}\text { Conservation } \\
\text { intervention }\end{array}$} & 4 & $\begin{array}{l}\text { Conservation intervention } \\
\text { type }\end{array}$ & $\begin{array}{l}\text { Possibilities include } \\
\text { protected/conserved area, } \\
\text { conservation of particular species, } \\
\text { sustainable use, restoration, or } \\
\text { mixture of those. Be as specific as } \\
\text { possible. }\end{array}$ \\
\hline & 5 & $\begin{array}{l}\text { Governance } \\
\text { arrangement/power relations } \\
\text { - who are main actors } \\
\text { controlling the design and } \\
\text { implementation of the } \\
\text { primary intervention }\end{array}$ & $\begin{array}{l}\text { May include community-based, } \\
\text { indigenous led, co-managed, } \\
\text { government run, non-governmental } \\
\text { organisation led, privately run } \\
\text { protected area. What role for IPLCs } \\
\text { initially and ongoing. If more than } \\
\text { one intervention then use numbering }\end{array}$ \\
\hline & 6 & $\begin{array}{l}\text { Any subtypes/secondary } \\
\text { interventions mentioned and } \\
\text { key characteristics (number if } \\
\text { more than 1) }\end{array}$ & $\begin{array}{l}\text { Could include tourism, benefit } \\
\text { sharing, species programs, human- } \\
\text { wildlife conflict program, capacity } \\
\text { building, tenure provision, farming, } \\
\text { livelihood program, participatory } \\
\text { land use planning etc. Key } \\
\text { characteristics may include }\end{array}$ \\
\hline
\end{tabular}


biodiversity target, incentive/benefit provided, level of participation, additional actors governing program etc.

7 Locality, country/ region

8 Name of primary intervention Site or program name given

9 Year primary intervention introduced (note any important changes and year they occurred)

10 Ecosystem type

E.g. Forest; Dryland/ semi-arid; Grassland; Shrubland; Wetland; Coastal; Marine; Mountain; Polar; Agriculture; Other

11 Any aspect of biodiversity Species, species groups, habitat, mentioned as the priority focus of the conservation intervention?

Well-being or social

dimension of governance
12 Specific well-being goals, social objectives, related governance features/equity principles associated with the conservation intervention?

13 Specific social groups targeted through the conservation intervention

14 Additional notes about conservation intervention/governance ecosystem, ecosystem services etc

List them

Local communities as a whole or any specific subgroups mentioned? If so, note pathway through which they are expected to benefit/be involved

Space for reviewer to note important information not covered by other questions 
Research methodologywell-being/ social research
15 What key social science terms, concepts, approach, framework are applied in the study's methodology?

16 How is this social dimension conceptualised? What aspects of IPLCs' well-being or equity are studied?
17 Research methods used to investigate well-being and links to conservation: method type/detail

18 Scale at which data is presented and at which analysis takes place.
May range from holistic, interdisciplinary study of all aspects of well-being to simpler focus on ecosystem services only in context of the conservation intervention/area/resource, to a quantitative economic approach focused on single resource type. Possible categories of focus include income/wealth, employment, infrastructure; different physical resource types including food, materials and access; human resources, education, skills; health; social cohesion, collective resources/ agency, leadership; trust, empowerment, relations, collaboration; cultural values and respect for identity, knowledge, practices. If land/resource tenure please specify what form of tenure considered (from property rights to customary, collective).

Qualitative: interviews, observation etc; Quantitative: survey data, spatial model etc ; Participatory, action research; Others

For example household level data may be analysed at the protected area level, between villages, nationally etc. Data may be at village, community, household, individual level, with analyses at local, 
subnational, national, international scales or cross-scale comparison.

This may not be clear for more descriptive case studies.

19 Whose well-being is considered in the study? Local communities as a Women, youth, the poorest, resource users, livelihood types etc. If wellbeing of other, wider stakeholders whole, Indigenous Peoples as a group or any specific subgroups within them?

20 Methodological assumptions to be considered when interpreting findings: Are there any clear ideological positions guiding the research? considered, are there any tradeoffs noted with well-being of IPLCs?

E.g. some researchers clearly assume (without themselves demonstrating) that material poverty is the primary cause of ecological degradation or that social and ecological outcomes will be improved through promotion of alternative livelihoods/ education/training regardless of local values or alternatively that Indigenous Peoples all exhibit proconservation behaviours.

21 Important contextual factors social, economic, political, environmental?

Any key details given on the status of well-being, livelihoods, equity or wider issues: major land use changes \& pressures, population density, conflict, political insecurity, natural disaster, economic forces, policies introduced etc.

22 What are the major changes Number if more than 1 in well-being (or other social term) shown or reported? What aspect of well-being has changed for whom and over what timescale? 
23 To what extent and through what mechanisms is conservation governance shown/reported to have caused or contributed to changes in well-being?

24 What are the other main causes or drivers given for those changes in well-being and through what mechanisms? (wider social, economic, political and environmental factors)

\section{Conservation} effectiveness

25 Conservation/ ecological effectiveness - how is it conceptualised in the study?

26 Effectiveness - what are the major changes shown or reported? Evidence of conservation success/nonsuccess, ecological state improving or otherwise?

27 To what extent and through what mechanisms is conservation governance shown/reported to have caused or contributed to changes in conservation effectiveness?

28 What other main causes or drivers have contributed to changes in effectiveness and through what mechanisms? (any local or wider social,
Try to mention a) specific feature of governance, $b$ ) pathway through which well-being influenced and c) how well-being affected for whom

Number if more than 1

(Refers to effectiveness in conserving biodiversity in some form, not simply effectiveness of management systems)

How has the change been evidenced? Is it assumed or described/quantified in some way?

Number if more than 1 . Try to mention a) specific feature of governance, b) pathway through which effectiveness influenced and c) how effectiveness has been affected

Number if more than 1 (e.g. invasive species, political insecurity, migration, climate change, agricultural policy or shifts, social change, economic forces, shift in 
economic, political and environmental factors)

Links between well-being and effectiveness
29 What are the key findings or conclusions reached about the relationship between wellbeing and conservation effectiveness or vice versa. If more than 1 please number each separate finding

30 Additional notes on wellbeing, conservation effectiveness and links between them

31 Any key recommendations made in the article for conservation or development policy/practice? demand for natural resources, land ownership change etc)

Number if more than 1. Possibility of multiple links, positive and negative, working synergistically, trading off against one another or mixed effects. Not only direct links but quite indirect. Provide any detail given about mediating factors or dynamics.

Space for reviewer to note important information not covered by other questions

Number if more than 1 